\title{
UM PERSPECTIVISMO AMERÍNDIO E A COSMOLOGIA ANÍMICA CHIQUITANA
}

ALOIR PACINI ${ }^{1}$

UFMT

RESUMO: Este texto reflete a respeito da perspectiva chiquitana do bem-viver que pode ser considerado um animismo, pois leva em consideração que todos os elementos da natureza possuem alma com os quais os Chiquitanos se relacionam. A compreensão da identidade étnica resiliente dos Chiquitanos se mostra na sua agência nas festas, nas relações dos devotos com os Santos e hitchis. Os diferentes rituais chiquitanos do curussé, das romarias, das festas de Santo e outros elementos revelam suas identidades e os constantes fluxos culturais pelo seu território tradicional.

PALAVRAS-CHAVE: Perspectivismo; Animismo; Chiquitano.

ABSTRACT: This work thinks over the chiquitano perspective of living, which can be understood as some sort of animism, once it deems that all elements of nature possess souls, to which the Chiquitanos relate. The understanding of the Chiquitanos' ethnic identity appears in theirs ceremonies and in the relationship of the believers with the Saints and hitchis. There are several rituals - such as curussé, romarias and festas de Santo - able to reveal the Chiquitanos' ethnic identity and the permanent cultural flow in their traditional territory.

KEYWORDS: Perspectivism; Animism; Chiquitano.

Esta concepção dualista de idealmente buscar simetria nas relações entre opostos vai se refletir nas formas de sensibilidade estética Kaingang e, conseqüientemente, no

\footnotetext{
${ }^{1}$ Professor do Departamento de Antropologia da UFMT, doutor pelo PPGAS da UFRGS em 2012, com a tese Identidade étnica e território chiquitano na fronteira (Brasil-Bolívia), sob orientação do Prof. Dr. Sérgio Baptista da Silva, cujo resumo está online no Espaço Ameríndio. (aloir.pacini@gmail.com). Este texto é parte da mencionada tese com as devidas modificações. Agradeço de coração as sugestões valiosas de Verone Cristina da Silva, doutoranda do PPGAS da USP.
}

Espaço Ameríndio, Porto Alegre, v. 6, n. 2, p. 137-177, jul./dez. 2012. 
ALOIR PACINI - Um perspectivismo ameríndio e a cosmologia anímica chiquitana

sistema de representações visuais, já que as 'marcas' (grafismos) opõem e, ao mesmo tempo, aproximam opostos (SILVA, 2002, p. 195).

\section{Introdução}

$\mathrm{Na}$ atual fronteira geopolítica do Brasil com a Bolívia, no estado de Mato Grosso, vive a etnia indígena chiquitana, falante da língua isolada vesüro ${ }^{2}$. As famílias habitam tanto área rural quanto urbana e estão inseridas em trabalhos agrícolas e domésticos ${ }^{3}$ ou, ainda, como "peões" de fazendas. Por serem considerados pacíficos pelos crucenhos $^{4}$ e fazendeiros brasileiros, são adotados tradicionalmente como bons trabalhadores.

Os tratados entre os impérios de Espanha e Portugal, as guerras e a independência do Brasil e da Bolívia definiram suas fronteiras à revelia dos habitantes desta região. Os Chiquitanos que justamente vivem ali são chamados de "bugres" pela população local e, atualmente, vivem numa "zona de tensão" pela afirmação ou negação da identidade, pelo direito ao seu território tradicional e garantia de suas tradições.

$O$ modo de ser e de fazer tradicional desta etnia indígena recebeu forte influência de missionários jesuítas entre os séculos XVII e XVIII e de outras tantas etnias indígenas deste vasto território que foram incorporadas ${ }^{5}$ nos ditos pueblos misionales. Houve uma síntese artística e religiosa própria do catolicismo. Após a expulsão dos jesuítas do

\footnotetext{
${ }^{2}$ Os Chiquitanos em geral, no Brasil, são bilíngues (português e espanhol), porém, em muitos casos, também trilíngues, falantes da língua chiquitana vesüro, preconceituosamente dita linguará.

${ }^{3}$ As aldeias chiquitanas que se autoidentificam indígenas são Vila Nova Barbecho, Acorizal, Central, Fazendinha e Santa Aparecida. Ali os Chiquitanos também estão inseridos em outros espaços e são professores, estudantes, agentes de saúde etc., mas não me alongarei a este respeito.

${ }^{4}$ Os de origem espanhola radicados em Santa Cruz de la Sierra (Bolívia) são assim chamados e são os primeiros que colonizam e escravizam os Chiquitanos. Passam para a história como os exploradores mais vorazes da Chiquitania.

${ }^{5}$ Considero que são mais de 40 etnias com suas culturas autóctones que foram agrupadas para formar o que atualmente é denominado Chiquitania, algumas desta região que hoje é Brasil, como os Saraveca, Kuruminaca, os Boe-Bororo, Guató, Nambikwara, Paresí e Guaná. As divisões internas que têm sua origem nas diferentes etnias que formaram a Chiquitania sob a influência dos jesuítas aparecem de diferentes formas nas devoções aos santos padroeiros das famílias e na forma de viver o curussé. Este aspecto religioso que identifica a maioria dos Chiquitanos é o modo atual dos Chiquitanos se apresentarem na sociedade brasileira em vista de um reconhecimento étnico e dos seus direitos territoriais subjacentes. Fundamental é conhecer este catolicismo próprio dos Chiquitanos para compreender seu modo de interagir atualmente com a sociedade envolvente e de se organizarem internamente.
}

Espaço Ameríndio, Porto Alegre, v. 6, n. 2, p. 137-177, jul./dez. 2012. 
Brasil (1759) e da Bolívia (1767), os Chiquitanos continuaram seus modos de serem indígenas, como é o caso da Missão de Santa Ana, San Ignacio e San Rafael.

Existem questões de fundo que provocam tensões nas relações complexas de alianças entre os fazendeiros e os Chiquitanos que trabalham para eles que sempre estouram no lado mais fraco. As pressões sofridas pelos Chiquitanos nas fazendas da região é um aspecto que deve ser melhor conhecido, pois os Chiquitanos estão mostrando os efeitos desastrosos desta ocupação intensiva com o gado para o equilíbrio do meio ambiente. São milhares os Chiquitanos que vivem nas cidades de Porto Esperidião e Cáceres, e grande parte da sua população está vivendo hoje nas periferias das cidades da região.

Este texto faz um diálogo com as concepções de Eduardo Viveiros de Castro (1996), Philippe Descola (2005) e Carlos Fausto (2001) aplicado a questões próprias dos Chiquitanos, como o curusséb e as festas de Santos. O aspecto central do texto a respeito da adoção familiarizante desemboca na noção de arte e estética, tão importante para os Chiquitanos. Para localizar esta temática, tomo a aldeia chiquitana da Vila Nova Barbecho (Brasil), que possui muitas raízes de seus membros no pueblo misional Santa Ana (Bolívia). Vila Nova Barbecho não é a única aldeia que sofre os desmandos da Justiça Federal, mas é um caso típico: uma Liminar do Juiz Federal determinou 325 hectares para esta comunidade e, em 6/12/2010, outro juiz decidiu impor novamente a cerca em torno de 25 hectares para liberar 0 restante das terras para o gado da Fazenda São Pedro, o que os obriga a passarem fome, pois as roças não são suficientes nesta pequena parcela

\footnotetext{
${ }^{6}$ Ouvi esta palavra a primeira vez no Porto Esperidião, em 2005 e, ao participar do carnaval ali em 2006, percebi que dizia respeito a este ritual religioso que acontece por ocasião do carnaval. O curussé do Porto Esperidião incorporou a figura do rei e rainha e grupos organizados, como Asa Branca e Nativo. Nas aldeias todos se envolvem neste ritual, o que permite que as brincadeiras de sujar um ao outro sejam mais livres. Na Vila Nova Barbecho o curussé ganha uma característica de disputa de gênero em que, nas brincadeiras, os homens sujam as mulheres; e as mulheres, os homens. Na aldeia Santa Aparecida enterram o Judas no final com uma garrafa de chicha e outra com tinta de urucum, no chamado carnavalito, que acontece no domingo depois do carnaval. No ano seguinte é nesta casa que inicia o carnaval ao desenterrar a chicha para beber e a tinta para pintar, num ritual de atenção aos corpos dos que vão bailar. Manoel Massaí Manacá contou-me no dia 27 de novembro de 2012 que passou a haver muita gripe na comunidade porque a fazendeira tinha proibido dançar o curussé em Santa Aparecida. Por isso faz dois anos que voltaram a dançar o curussé. Não tenho dúvida de que a palavra curussé vem de curusürch, que, em vesüro, quer dizer cruz, pois é no carnaval que acontece a maioria dos "sermões" que os Chiquitanos fazem em vesüro, onde Jesus pede que se alegrem enquanto ele está com eles e Jesus mesmo ensina a tocar os instrumentos, porque chegará a hora em que ele será pregado na cruz.
}

Espaço Ameríndio, Porto Alegre, v. 6, n. 2, p. 137-177, jul./dez. 2012. 
do seu território tradicional. Penso que a demarcação de um território chiquitano deve considerar muito mais que a terra simplesmente, mas este elemento intrinsecamente associado à água e os seus significados. Este território chiquitano se define pelos comportamentos, pelos costumes, pelas línguas faladas, pela produção cultural, gastronomia, festas, enfim, todo um repertório que "repatria" indivíduos e grupos para dentro de um sistema de objetos que são valorizados e cultivados. Neste sentido não existe a fronteira que divide, mas um conjunto de práticas que permitem esta identidade étnica diferenciada da população geral do Brasil e da Bolívia na fronteira.

Este texto se propõe a mostrar a importância do território tradicional não como afirmação categórica, mas como forma de garantir outras práticas dos Chiquitanos, entre elas as festas, as roças e tudo que exige de recursos naturais para que aconteça a vida em comunidade segundo os costumes chiquitanos.

\section{Os Santos e suas imagens}

Desde os primeiros momentos de contato com os Chiquitanos, ressalta à vista dos observadores o cuidado que possuem com as imagens dos Santos 7 , o valor que ocupam nos seus oratórios familiares e nas igrejas. Relacionam-se com os Santos como membros da sua família ou da sua comunidade, geralmente com o lugar de maior destaque como o Pai ou a Mãe, são os patronos! Nas práticas rituais, estes Santos são identificados com as imagens que possuem em suas casas ou nas igrejas sem fazerem as mediações teóricas que geralmente se faz a partir de conceitos como representar, simbolizar, lembrar, recordar. Estas observações etnográficas nas festas de Santo e no cotidiano aparecem também tanto no curussé quanto na Romaria de Santa Ana, nas Missas e nas Procissões: Param o cortejo do Santo para uma pessoa que chega e esta se ajoelha, fala com o Santo, pede bênçãos sob o olhar de todos, que observam com paciência e só depois

\footnotetext{
${ }^{7}$ Neste texto quando falo dos Santos não os substancializo mas não estou prescindindo das suas imagens, porém penso que está de acordo com a cosmovisão chiquitana este procedimento de não distingui-los linguisticamente como era de se esperar de um procedimento científico formal.
} 
segue a procissão. Esta relação com os Santos é prioritária e aos poucos vão cumprimentando também os demais Chiquitanos que chegam com a Romaria, por exemplo.

As comunidades chiquitanas formam verdadeiras redes de comunicações com seus nós, ultrapassando as fronteiras criadas pelas sociedades nacionais. As histórias de vida e das comunidades com sua religiosidade e cultura próprias representam elos de continuidade espaço-temporal que quero registrar. Essas relações entre os nós de cidades-santuários ou igrejas atuais permitem intercâmbios e fluxos de referência territorial e de identificação em diferentes pontos fundamentais, como o Portal do Encantado, a Serra do Barbicho, o Lago Grande, a Serra de Santa Bárbara etc. Aqui a fronteira pode ser compreendida como tensão entre os países, entre os fazendeiros e indígenas e mesmo entre os próprios Chiquitanos. Contudo, nos momentos de curussé (ou carnavalito) ou festas dos padroeiros são desfeitos os conflitos entre os opostos e se conectam as fronteiras a fim de que todos os Chiquitanos se encontrem para a grande festa onde a norma básica é "pular" e dançar.

A dança do curussé, realizada pelos Chiquitanos durante o período do carnaval do calendário cristão, faz a síntese do território e da identidade étnica ${ }^{8}$, uma espécie de casamento que se expressa comumente nestes momentos de festa: "Bateu a caixa, o bugre pula e bebe chicha". Para isso tocam seus tambores, suas flautas e pífanos, bebem muita chicha, fazem seus cortejos com bandeiras e percorrem as casas de todos que moram na Vila Nova Barbecho. Estes agradecem, devotamente, esta chegada das bênçãos ancestrais. Joga-se barro, tinta e cinza uns nos outros para marcarem seus corpos, isso mais intensamente nas aldeias que se reconhecem indígenas no Brasil do que na Bolívia ou lugares com densidade populacional maior. No final da terça-feira de carnaval, acontece a reconciliação diante do altar em alguns aldeamentos Chiquitanos no Brasil.

\footnotetext{
${ }^{8}$ Em todas as vezes em que estive presente no curussé da Vila Nova Barbecho, houve ampla participação nos rituais, mesmo os que não se engajam na luta pela demarcação do território tradicional porque aliados ao fazendeiro, todas as famílias dançam e oferecem chicha, passando de casa em casa num movimento circular da direita para a esquerda que começa na capela e ali conclui com o ritual da reconciliação no anoitecer de terça-feira.
}

Espaço Ameríndio, Porto Alegre, v. 6, n. 2, p. 137-177, jul./dez. 2012. 
Outro traço peculiar dos Chiquitanos é os caminhos das águas e os percursos pelo território tradicional. As nascentes e cabeceiras brotam da "coroa do mundo" (na Serra de Monte Cristo ou Santa Bárbara, em Santa Ana e outros lugares deste divisor de águas da Bacia do Paraguai e do Amazonas) e formam córregos e rios fundamentais para a sobrevivência física e cultural desta etnia. Nas cabeceiras do Encantado e do Nopetarch, como de outros córregos, existem hitchis, "donos que protegem as águas", "amos das águas e dos peixes"9.

Também a Romaria de Santa Ana, que sai do território Chiquitano na Bolívia e passa pelo território Chiquitano no Brasil, é outra forma de demonstrar essa forte ligação dos Chiquitanos com o seu território tradicional (com a Coroa do Mundo), as águas, os caminhos e percursos dos devotos em forma de rosários com muitas contas, que conectam e ligam a chiquitania pelos fios religiosos porque deixam o sagrado permear toda a Chiquitania. O roteiro da Romaria começa com os Chiquitanos vindo de Santa Ana, na Bolívia, e atravessando a fronteira do Brasil, passando pelas diversas comunidades numa espécie de ligação ancestral ritualística e sagrada, como caminhos visíveis que tecem as redes sociais e de parentesco, suas (re)ligações com o território tradicional. Trata-se de uma travessia que os aproximam, um compromisso sagrado que continua sendo percorrido em busca de suas identificações, que os tornam etnicamente capazes de se fazerem indígenas com direito à vida, a terra, à água, ao alimento, à família, à comunidade... à etnia!

Em cada comunidade, os depoimentos dos seus moradores ressaltam aos olhos do espectador sua religiosidade profunda. As imagens de produção, de trabalho, de jogos e brincadeiras, de rezas, de festas, de ritos e de sonhos dizem mais que palavras. Ao alinhavar, nestas buscas, o sentimento dos Chiquitanos, suas lutas, seus temores, suas crenças e suas mitologias (religião), sua língua e linguagens, encontramos o trabalho de suas mãos e mentes - produção de bens materiais e simbólicos -, que definem suas identidades características.

Os Chiquitanos são hábeis na fabricação de arte esculpida em madeira (santos, anjos, máscaras e outros) e nas atividades manuais em

\footnotetext{
${ }^{9}$ Observe abaixo estes elementos expressos em imagens esculpidas em madeira, que mesclam formas angelicais com sereias nas igrejas chiquitanas de San Rafael, de 1696, e San Miguel, de 1734.
} 
geral: usam e confeccionam redes, potes de cerâmica onde armazenam água e chicha. Num passado recente também utilizavam as urnas funerárias para significar a nova gestação de seus membros que partiam. Tecem cestos e chapéus de palha de buriti, e os bordados são constantes em tecidos que adornam as casas e vestes com temáticas que mesclam elementos da natureza e motivos religiosos propriamente ditos.

Reflexões mais sistemáticas em relação aos aspectos culturais são necessárias para compreender esta riqueza de dados. As Escolas de formação básica e média e a Escola de Música Espírito Santo dos Chiquitos são acompanhadas como processos de interlocução neste campo da fronteira ${ }^{10}$. As escolas diferenciadas indígenas possuem mecanismos de recuperação do vesüro, porém a falta de uso no cotidiano nas famílias a coloca como segunda língua.

Introduzi aqui o que aglutina os Chiquitanos como etnia e as relações com as fronteiras, com as disputas de terras diferentes entre os indígenas nas aldeias, nas periferias das cidades e nos trabalhos das fazendas. Os modos como vivem sem a propriedade do seu território tradicional mostram as fronteiras nos olhos de quem vê as cercas da propriedade privada, dos latifúndios e dos Estados Nacionais. Os movimentos cotidianos que delimitam suas ações, o contexto em que vivem e suas manifestações mais básicas ou sagradas são por si só uma denúncia de falta de cidadania dos Chiquitanos no Brasil.

\section{Algumas mediações teóricas}

Para pensar a perspectiva chiquitana dos acontecimentos que os envolvem, passo rapidamente pela ideia de animismo para ressaltar o núcleo máximo de sociabilidade que acontece na aldeia ou cidade santuário e vai se diluindo até os lugares mais distantes, chamados de

\footnotetext{
${ }^{10}$ Trata-se de um esforço conjunto para incentivar as músicas tradicionais chiquitanas, que sofrem o afluxo das músicas veiculadas pelos diversos meios de comunicação e pelas bandas. O incentivo para os instrumentos musicais tradicionais possuem momentos fortes de esforços com mecanismos internos que se mantêm ainda para o aprendizado do pífano, flauta, caixa e bumbo. Contudo, para instrumentos que haviam se perdido, como é o caso do violino, violoncelo, violão e outros, é necessário trazer professores Chiquitanos de outras comunidades.
} 
montes, onde os animais são tratados como cunhados. Neste caso dos Ashuars, o quintal e a roça é ainda local de relação familiar onde as plantas cultivadas são tidos como filhos. Philippe Descola (2005) apresenta quatro modos de continuidade e descontinuidade entre natureza e cultura, a partir deste binário da interioridade e da materialidade, também relacionado à alma e ao corpo. A natureza determina a cultura ou a cultura dá sentido à natureza? Uma antropologia "materialista" e "simbólica" é necessária para compreender a percepção chiquitana de que se compartilha com o "outro" e também com a "natureza" uma mesma essência e uma mesma origem ontológica.

O totemismo implica uma identidade moral e material de uma unidade social com um objeto natural, "uma representação icônica simples" (DESCOLA, 2005, p. 105) em que plantas e animais se vêem com atributos antropomórficos e sociais (cosmomorfismo). Encontrei, em diferentes oportunidades, o aspecto dos seres protetores dos animais, montanhas, águas e outros entes chamados hitchis. Aqui importante é mencionar que estes seres são "donos", protetores destes aspectos da natureza, possuem uma espécie de agency humana. Talvez seria o caso de olhar os Santos padroeiros como totens e hitchis de comunidades e famílias chiquitanas. Contudo parece-me que este modo de expressão não dá conta da realidade, pois encontrei resistência na sensibilidade chiquitana ao associar os hitchis aos Santos ou a pessoas concretas porque estes seres são polivalentes e podem provocar o mal, não estariam "civilizados"11 como os Chiquitanos.

$\mathrm{Na}$ visão de mundo animista12, as plantas e os animais possuem uma alma comum à condição dos seres humanos, porém materialmente diferentes, uma espécie de roupagem, na linguagem de Eduardo

\footnotetext{
${ }^{11}$ Os dados etnográficos indicam a perspectiva sociológica chiquitana de incorporação dos "bárbaros" dos montes nos pueblos misionales. Penso que isso foi assumido como ideologia de incorporação do outro ao mesmo, como forma de familiarização dos inimigos tradicionais. O fato dos hitchis serem por vezes tidos como inimigos com quem se deve negociar ou, ao menos, como apareceu frequentemente no campo, seres perigosos aos quais se deve respeitar, esta cosmologia permanece entre os Chiquitanos.

${ }^{12} \mathrm{O}$ animismo foi lido e interpretado pelos antropólogos como uma visão "equivocada" dos indígenas, o que não deixa de ser um preconceito. É prudente procurar expressar melhor o que penso a respeito, pois se trata de algo que vem da perspectiva indígena na qual todos os seres da natureza possuem alma que os ligam com os demais seres do universo, subjacente a esta visão está a proposta indígena do bem-viver, ultimamente divulgada a partir da Bolívia e do Equador.
}

Espaço Ameríndio, Porto Alegre, v. 6, n. 2, p. 137-177, jul./dez. 2012. 
Viveiros de Castro (1996), e forma na tradição filosófica ocidental para mostrar o específico de cada interioridade:

\begin{abstract}
Estas roupagens específicas induzem perspectivas diferentes sobre o mundo na medida em que as determinações fisiológicas e perceptivas próprias de cada corpo impõem a cada classe de seres uma posição e um ponto de vista particulares (DESCOLA, 2005, p. 107).
\end{abstract}

Nesta perspectiva do animismo, a natureza está englobada pela cultura, e os seres humanos se utilizam das categorias elementares da prática social de reciprocidade, predação e dependência, para pensar as relações entre os humanos, os vegetais e os animais, ou seja, há identidade de almas "humanas" e diferença de corpos numa espécie de antropocentrismo. Penso que também o animismo não dá conta de expressar a experiência dos Chiquitanos de estarem neste mundo da fronteira ou na fronteira deste mundo.

Já o analogismo supõe uma descontinuidade gradual das essências numa cadeia dos seres. Trata-se do cosmocentrismo associado à astrologia, um aspecto do mundo chiquitano que não cheguei a tocar. Mais precisamente, o analogismo

Repousa sobre a idéia de que as propriedades,
movimentos ou modificações de estrutura de certas
entidades do mundo exercem influência à distância
sobre o destino dos seres humanos ou estão influídos
pelo comportamento humano (DESCOLA, 2005, p.
108).

Então o naturalismo parece-me completar este passeio como cosmologia própria dos nossos tempos de ecologia exacerbada, postula uma identificação da natureza com um "mundo" estranho à vontade e cultura humanas que permitem sua existência (pressupõe uma descontinuidade das interioridades e uma continuidade material).

Semelhante fórmula fará coexistir não uma pluralidade de mundos, mas uma enorme quantidade de pequenos pedaços de mundo recompostos segundo as tradições locais e as idiossincrasias individuais e familiares por seus elementos, ainda que originais por suas valências específicas, uma maneira nova e indispensável de introduzir a diversidade na grande unificação formal 
que o mercado começou a empreender (DESCOLA, 2005, p. 111).

Os Chiquitanos, como qualquer outra etnia, não pertencem a uma ordem estática, mesmo que a identidade no campo da arte material tenda a cristalizar-se. Porém parece-me que os Chiquitanos estão "decididos a continuar como índios, ainda criam e sempre recriam importantes obras de arte dotadas de notável especificidade histórica e cultural" (VIDAL, 1992, p. 13). O desejo de transformar o corpo e a alma humana é recorrente em todas as culturas. Assim, a perspectiva animista, por mais incongruente que possa parecer ao mundo científico ocidental, poderia ser uma forma de todos os seres se verem, conectados intrinsecamente. A tradição chiquitana brasileira dos trançados de buriti, dos potes que usam para preparar a chicha e as formas de dançar e festar marca até este momento suas manifestações culturais. As pinturas corporais 13 aparecem nas suas manifestações públicas com insistência nos últimos tempos. No novo contexto de reafirmação política procuram identificarem-se para fora como indígenas, o que está relacionado a relações com outras etnias, reinventam suas tradições elegendo determinadas pinturas, como a do surubi.

Dominique Gallois (1992, p. 209-230) fez um estudo dos Waiãpi (Tupi-Guarani), em que o corpo humano é visto enquanto tela social as propriedades dos corpos animais e divinos podem ser encontradas no corpo humano. O corpo é a tela que faz a sua ligação cosmológica com os deuses. Podem predar as propriedades cosmológicas dos outros, corporificados às vezes nos seres ancestrais.

Também a experiência vivida nos rituais é de grande envolvimento emocional, como se fossem conquistar um afim para uma relação de casamento com os Santos e apropriar-se dos seus atributos, que podem passar para os devotos ou seus filhos nesta relação conjugal de intimidade.

\footnotetext{
13 "Apenas recentemente a pintura, a arte gráfica e os ornamentos do corpo passaram a ser considerados como material visual que exprime a concepção tribal da pessoa humana, a categorização social e material e outras mensagens referentes à ordem cósmica" (VIDAL, 1992, p. 13).
} 
Observei mais uma vez com detalhes a escolha de que pintura usar nos corpos dos 36 Chiquitanos do Brasil quando decidiram participar no Manifesto contra a Portaria 303 da Advocacia Geral da União (AGU) e fecharam a estrada de São Vicente, perto de Cuiabá, entre os dias 27/08 e 31/08/2012. Percebi que a pintura era decoração e informava sobre um sistema de comunicação visual e relações entre as etnias indígenas e com o mundo dos espíritos que ainda não são dominados em todos os seus aspectos, parece-me. A decoração do corpo (dos Santos) ou a vestimenta cerimonial tão apreciada pelos Chiquitanos, em geral, ou dos Santos em particular, os identificam, talvez com as etnias subjacentes, como é o caso da família dos Surubis, que tinham marcadas sua pintura corporal apropriada pelos demais Chiquitanos.

Em geral os Santos na Chiquitania são vestidos com roupas novas a cada festa, por vezes recebem perucas com cabelos que os fazem parecerem mais com os seres humanos devotos, como se as vestes e os cabelos fossem mediações e agentes de santidade que aproximam os opostos! Parece-me que um aspecto importante neste contexto é que as vestes dizem respeito especialmente à civilização chiquitana, que os Chiquitanos se sentiriam mais civilizados vestindo roupas e usando sapatos. A eficácia simbólica dos revestimentos corporais leva à plenitude da pessoa na relação com o mundo sobrenatural.

Como os Santos são de origens distantes, ou seja, estão no mundo dos colonizadores, estes Outros (inimigos, brancos, mortos, animais, vegetais) devem ser pacificados, familiarizados, moldados, esculpidos, ou seja, civilizados! Os hitchis são metamorfoseados em diferentes perspectivas como "donos das águas" e, neste ambiente, controlam os animais aquáticos, como dono da Serra Santa Bárbara, dono do cusi (babaçu), cuchi (cerejeira), osbi (jenipapo), cedro-amargo (Cedrela odorata L.), almesca (pau-de-breu), buriti (Mauritia flexuosa) etc.

Os padrões gráficos e estéticos dos artefatos especificamente das igrejas chiquitanas são representações dos seres sobrenaturais do mundo cristianizado, os Santos com os quais os Chiquitanos se identificam são parte deste universo. As esculturas antropomorfas em madeira e em argila, ou as pinturas podem representar figuras 
totêmicas com grande agência espiritual sobre os Chiquitanos. O material utilizado, a madeira, a argila, as tintas estão relacionadas às técnicas de moldagem, escultura e de pintura e à "santidade" dos Santos para os Chiquitanos.

O urucum é misturado com gordura de animais e óleos vegetais e aplicado de maneiras diferentes para conseguir pintar de vermelho, uma cor muito apreciada pelos Chiquitanos. O jenipapo é utilizado com pincéis ou pauzinhos, carimbos ou chumaços de algodão para conseguir a cor preta nas pinturas corporais das aldeias no Brasil. A fruta de jenipapo é coletada ainda verde e colocada na cinza ainda quente para completar o seu amadurecimento. Depois de ralada, seu sumo é depositado numa cuia para, em seguida, ser utilizado na pintura das esculturas e do corpo. As resinas de diversas árvores, como a copaíba, para dar brilho e proteger as imagens; a maçaranduba e o patchu/i ${ }^{4}$, geralmente, são usadas para dar cheiro bom às pinturas e têm um valor simbólico porque é também "remédio de cheiro". A utilização de diferentes cores de argila para a pintura das paredes e tetos das Igrejas também são utilizadas para pintar os corpos no currussé e são sinais desta Chiquitania. Como as esculturas, os "desenhos marcam a alteridade de quem os utiliza. Eles estão associados à metamorfose das pessoas" (GALLOIS, 1992, p. 226). O modo de fazer os potes na Vila Nova Barbecho ou mesmo o modo de tocar as músicas e dançar o curussé, por exemplo, mesmo que forem obras de arte atuais, todas expressam esta compreensão e cosmovisão chiquitanas.

A linguagem do corpo dos Santos esculpidos em madeira também diz respeito à aproximação do mundo dos mortos, uma vez que estes Santos já passaram por esta vida, morreram no seu corpo como o nosso e estão vivos no lugar dos encantados e parecem que estão revividos nas esculturas feitas pelos artesãos Chiquitanos. Os diferentes modos de revestimentos da alma humana são as roupagens, as pinturas e as orações dos devotos que alteram a posição do Santo em relação ao Outro transcendente e aos outros seres humanos.

\footnotetext{
${ }^{14}$ Patchouli, patchouly, pachouli, pachuli, patechuli, patexulí... também oriza no Brasil, é o nome dado tanto a um conjunto de espécies do plantas do gênero Pogostemon quanto ao óleo essencial obtido de suas folhas.
} 


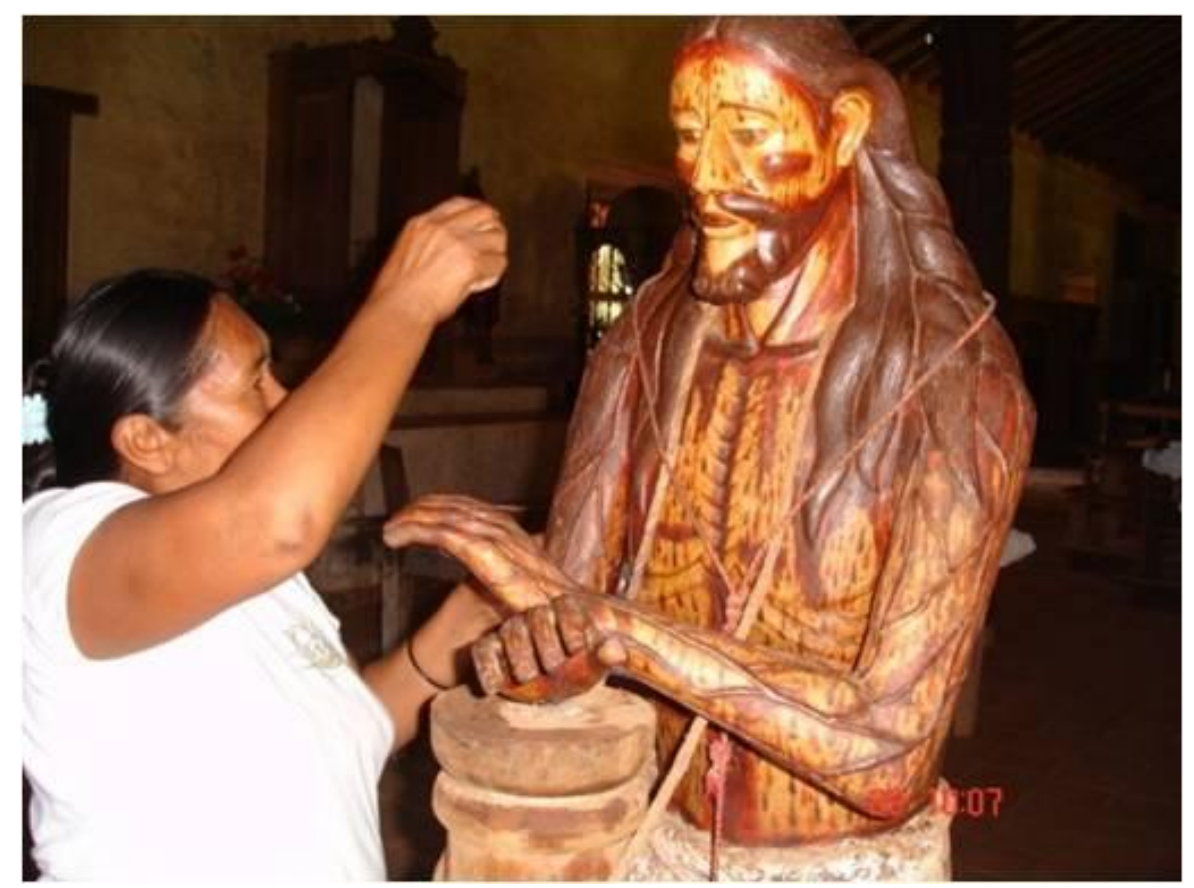

Imagem 1: Limpeza com óleo de copaíba da imagem de Jesus flagelado e torturado, atado ao tronco (Santa Ana, em 29/03/2010).

Nas três Romarias de Santa Ana em que participei (2009, 2010 e 2011) e nas festas em Santa Ana de Velasco (Bolívia), percebi que na maioria das vezes a devoção se torna oração e desperta o desejo dos mortais para a vida eterna, numa espécie de morada celeste. Nos rituais, os anenhos 15 procuram uma aproximação com o mundo celeste, dançam para serem ouvidos pelo Criador, os Santos os aproximam dos "mortos" sem riscos porque são pessoas que já passaram pela morte e a comunidade em ritual segue o protocolo para atingir a adesão dos Santos através de prescrições na forma como se relacionam com a imagem e fazem religiosamente a festa para o Santo patrono da comunidade ou da família. Don Lourenço pediu para eu trazer velas para ele poder acompanhar a nossa Missão. Partes do círio pascal de Santa Ana são levadas nos bolsos dos caçadores como guias para não se perderem na mata.

Como a pintura, as tatuagens, também a cruz de Tupã (tupana kuruça) era pintada na testa dos homens para proteger das armas de fogo, "chumbo não acerta", diziam os Waiãpis e dizem também os

\footnotetext{
15 Anenhos são os nascidos em Santa Ana, neste caso em Santa Ana de Velasco, um pueblo misional fundado pelo Padre Julian Knogler, SJ, próximo da fronteira do Brasil atual, em 1755.
} 
Chiquitanos. Através da arte é possível intervir sobre a realidade, pois a "arte iconográfica Waiãpi representa [...] o controle sobre a floresta, os animais e a água” (GALLOIS, 1992, p. 229).

Os Santos que estão presentes nas igrejas em geral não possuem indicação de escultor nem de época, mas são imagens elaboradas no processo do cristianismo chiquitano ${ }^{16}$. O rosto mais afilado poderia indicar um artista jesuíta e os rostos mais arredondados, arte dos Chiquitanos? Parece-me, porém, que este critério não é universal, pois os Chiquitanos são dados à imitação e poderiam também fazer esculturas com traços dos missionários ou das imagens já feitas pelos missionários estrangeiros. Contudo neste momento não é tão importante quem foram os artistas que deixaram estas imagens.

\section{A perspectiva do diferente}

O governo do Brasil ainda não compreendeu o nosso sistema! (cacique Fernandes Muquissai Soares, Vila Nova Barbecho).

Carlos Fausto traz um modo de abordar e aprofundar o perspectivismo ameríndio (FAUSTO, 2001, p. 418-468) por meio de sua pesquisa sobre os rituais parakanã de predação ${ }^{17}$ e familiarização. Ali encontrou uma forma de consumo e apropriação das capacidades do inimigo: a predação familiarizante que é pensada como filiação adotiva (na relação senhor-xerimbabo ${ }^{18)}$ e uma negação "fecunda" do inimigo ou do diferente. Fausto centrou-se na teoria nativa da produção,

\footnotetext{
${ }^{16}$ Hoje alguns artistas que esculpiram imagens diversas dizem que sua marca fica na imagem, porém esta nova sensibilidade parece ser fruto do nosso tempo em que a autoria tem valor muito distinto do passado. ${ }^{17} \mathrm{O}$ conceito de predação é adequado aqui porque diz respeito à caça, mas não é somente isso, pois traz consigo a compreensão de relação sexual no sentido usado na linguagem popular "comi aquela mulher!" e das relações matrimoniais e de compromissos do patrão com o empregado, do Santo com seu devoto, e subjacente está também o conceito de antropofagia, que não poderei aprofundar neste momento.

${ }^{18}$ Nesta relação o animal "domesticado" reconhece o chamado do "dono", que assobia, e ele vem. No perspectivismo ameríndio os seres estariam em contínua predação, por isso o inimigo precisa estar à altura para a relação e trazer suas propriedades ao predador. A guerra é uma forma particular de consumo, preocupado com a produção de corpos e pessoas, trazer as propriedades para dentro de seus corpos na predação dos afins. O modo guerreiro e xamânico de participar do ritual leva a pensar que não posso matar meu animal de estimação, meu xerimbabo. Para Fausto, a predação familiarizante parakanã é mais rebuscada que dos Araweté (VIVEIROS DE CASTRO, 2000).
}

Espaço Ameríndio, Porto Alegre, v. 6, n. 2, p. 137-177, jul./dez. 2012. 
maturação e desaparecimento da pessoa. Penso que a idealização dos Santos projetados como patronos e as igrejas como casas de Deus e portas do céu para a conformação de uma comunidade seja uma forma de produção dos Chiquitanos enquanto pessoas humanizadas e civilizadas. Talvez por isso passam a noite da véspera do dia da festa do padroeiro em "velório" na igreja, gerando a comunidade para o dia todo sagrado, o dia do Santo! Observei isso nas festas de padroeiros em que estive presente e os comentários são que, na véspera, já se pode perceber a intensidade da força do Santo festejado, por isso é importante iniciar o dia do Santo (meia-noite) acordado, esperando.

Penso que da mesma forma a "comunhão" no corpo e sangue de Cristo, o ritual do qual participam os Chiquitanos desde o tempo missional ou mesmo a escolha de um Santo patrón da comunidade ou da família, e ainda a escolha dos padrinhos para os filhos segue esta mesma lógica da predação do diferente, geralmente do estranho ou inimigo de difícil domínio. Neste caso o ritual de distribuição de chicha ${ }^{19}$ segue normas precisas para que os possocas ${ }^{20}$ se sintam incluídos na festa.

A imbricação entre guerra e xamanismo, da predação e da familiarização marca os sistemas tupi-guarani, e parece ser herança também dos Chiquitanos, aos quais se incorporaram muitos guarani. Fausto analisa a guerra como consumo produtivo, uma simbólica da predação canibal para uma simbólica da fertilidade. A produção de pessoas por meio da antropofagia é passar de matador-vítima para genitor-prole: "O ritual do bastão expressa a equivalência da relação entre senhor-xerimbabo e pai-filho, manifestando o sentido da passagem da guerra ao xamanismo - ou, genericamente, da predação à familiarização" (FAUSTO, 2001, p. 455). No modo de organização social chiquitano, alguns vestígios da fabricação de pessoas por meio da sua negação podem estar na predação guerreira, na familiarização onírica,

\footnotetext{
${ }^{19}$ Para os Chiquitanos brasileiros, chicha é a bebida fermentada de milho ou mandioca que deixam por dias dentro dos potes de barro; e o aluá, que também é feito com milho fofo torrado, é servido logo, não é fermentado. A ingestão de bebidas se dá num ambiente de festa e modifica o corpo da pessoa, talvez por isso a bebida alcoólica entrou com força e passou a ser distribuída também, o que deixa quase todos borrachos no final da festa.

${ }^{20}$ Estes são os visitantes, os de fora que chegam para a festa e possuem um lugar especial no contexto dos festejos, por vezes dá a impressão que as festas são para os que vêm de outras comunidades, principalmente as autoridades, e os Chiquitanos se esmeram para que os possocas se sintam bem na festa e falem bem dela.
}

Espaço Ameríndio, Porto Alegre, v. 6, n. 2, p. 137-177, jul./dez. 2012. 
na ceva de animais, na reinimização dos que se associam aos fazendeiros, na captura e predação ritual das agências dos Santos. Os Chiquitanos se reproduzem nas relações sexuais como qualquer outra etnia, mas existe um processo de civilização e culturalização que é próprio para esta "criatura" que vem ao mundo: um Chiquitano passa pelo batismo na água e no óleo, dando-lhe um nome, e pelo aprendizado de suas tradições, que o identifica.

Existem também rituais que aparecem como a apropriação de uma alma e/ou do sangue da vítima. Os Arara do médio Xingu possuem o ritual ieipari ou kuarup, em que o inimigo é representado por um pau sobre o qual coloca-se o crânio da vítima de guerra. O pau é abraçado como parente ou espancado como inimigo, é amante das mulheres que roçam sua vulva contra ele. Uma panela de chicha fermentada é colocada aos "pés do pau" para as mulheres beberem como se fosse um filho para se tornarem férteis (TEIXEIRA-PINTO, 1996, p. 93). Quando etnografei o parto de Tamara, em 25/09/2006, percebi o domínio que o pajé Lourenço Ramos Rupe tinha sobre a tradição chiquitana. No resguardo de diferentes mulheres, amarram a cabeça com um pano, protegem a criança em lugares reservados. Neste período, há uma espécie de captura e/ou domesticação do espírito do "inimigo" ou da natureza, que passa a habitar este mundo como um Santo, ou seja, passa a ocupar um lugar especial do qual provém as graças solicitadas. Observei que no local dentro da igreja onde foi fincada a cruz na sextafeira santa, em Santa Ana, depois de baixar Jesus morto e levá-lo ao sepulcro e retirada a cruz, deste buraco os Chiquitanos retiram terra e cinza para fecundar suas roças e rebanhos.

Carlos Fausto (2001) observa que as cosmologias anímicas associam o mundo transcendente, o mundo dos objetos criados e dos animais. Os parentes (te'ynia) pautam suas ações no ideal de troca e retribuição. O lugar que os brancos passaram a ocupar na economia simbólica da alteridade é distinto, foram associados ao pólo do demiurgo. Assim, a relação entre os Chiquitanos com as imagens dos Santos pode ser lida como uma espécie de predação da força dos Santos, um regalo de graças da parte do Santo e uma fidelidade por parte dos Chiquitanos aos rituais deixados que perduram até os nossos 
dias. A busca do pajé de outra aldeia ${ }^{21}$ para colocar ou tirar alguma doença é fundamental para o equilíbrio de forças entre os Chiquitanos, que têm medo da inveja porque transforma o coração das pessoas e gera a ganância pela posse da terra em grandes fazendas.

Entre os Parakanã e os Chiquitanos, o controle dos espíritos das vítimas nas guerras acontece pela domesticação; e dos espíritos familiares, geralmente animais, pelo xamanismo: "Para ser produtiva, contudo, a predação ontológica deve converter-se em sua contraparte, a familiarização, que é o esquema de interação com os entes incorporais dotados de agência" (FAUSTO, 2001, p. 369).

A família é um ens incompletum que pode se reproduzir com a predação de animais que são subjetivados para servirem de puro alimento (produção consumptiva, consumo para produzir o corpo) e a predação de humanos ${ }^{22}$, um consumo produtivo para a produção de novas subjetividades (antropofagia e casamento com os afins). Então se precisa a familiarização dos espíritos das vítimas na guerra e dos espíritos familiares no xamanismo para o equilíbrio das relações entre os Chiquitanos e com os fazendeiros.

\section{O cristianismo se inseriu neste mundo chiquitano}

O cristianismo se inseriu entre os Chiquitanos através da Missão de Chiquitos $^{23}$ e aqui vou somente retomar alguns aspectos que se fazem necessários para compreender de fato os Chiquitanos que inculturaram $^{24}$ sua fé de forma única. Parece-me que não houve

\footnotetext{
${ }^{21}$ Não há santificação local dos jesuítas que trabalharam na Missão de Chiquitos no sentido de devoção a eles, mas a sua associação aos pajés "de fora" e uma mitificação deste período original.

${ }^{22}$ Entre os Rikbaktsa, também antropófagos no passado, observei que as pessoas mais dóceis e pacíficas eram destinadas a matar o inimigo porque tinham controle de seus impulsos e depois do acontecido viviam tranquilos na aldeia. Os Chiquitanos, também antropófagos (CABALLERO apud SANZ, 1933, p. 17), possuem esta docilidade e a predação se dá pela maneira como se apropriam do externo, do diferente.

${ }^{23}$ Num nível mais propriamente religioso, a concepção chiquitana é que os males são colocados dentro de seu corpo e provocam doenças, e esta ação necessita outra semelhante para a retirada do mal, o que é feito pelo pajé. Na chicha, na comida e na Eucaristia, se apropriam do outro como benefício, como alimento, mas ali também pode ser colocado o veneno.

${ }^{24} \mathrm{O}$ conceito de inculturação foi usado primeiramente por Pedro Arrupe quando era o Padre Geral dos jesuítas, em 1964, e tem como sinônimo a inserção, ambos dizem respeito, inicialmente, ao fenômeno da entrada de Jesus Cristo no mundo dos pobres e das culturas humanas a partir da encarnação dentro do povo de Israel. Este conceito surge quando entram em desuso categorias aparentadas de aculturação e
}

Espaço Ameríndio, Porto Alegre, v. 6, n. 2, p. 137-177, jul./dez. 2012. 
simplesmente uma identificação dos conquistadores com as divindades. Não há devoção na Chiquitania pela memória de nenhum dos jesuítas missionários que por ali passaram. Porém os jesuítas foram associados aos xamãs, pois andavam de aldeia em aldeia profetizando a vida edênica, convidando para a Missão de Chiquitos, uma espécie de "terra sem males" dos Guarani. Parece-me que os "deuses" trazidos (Jesus Cristo e os Santos) é que foram associados aos conquistadores e entre eles estavam os jesuítas San Francisco Javier e San Ignacio de Loyola.

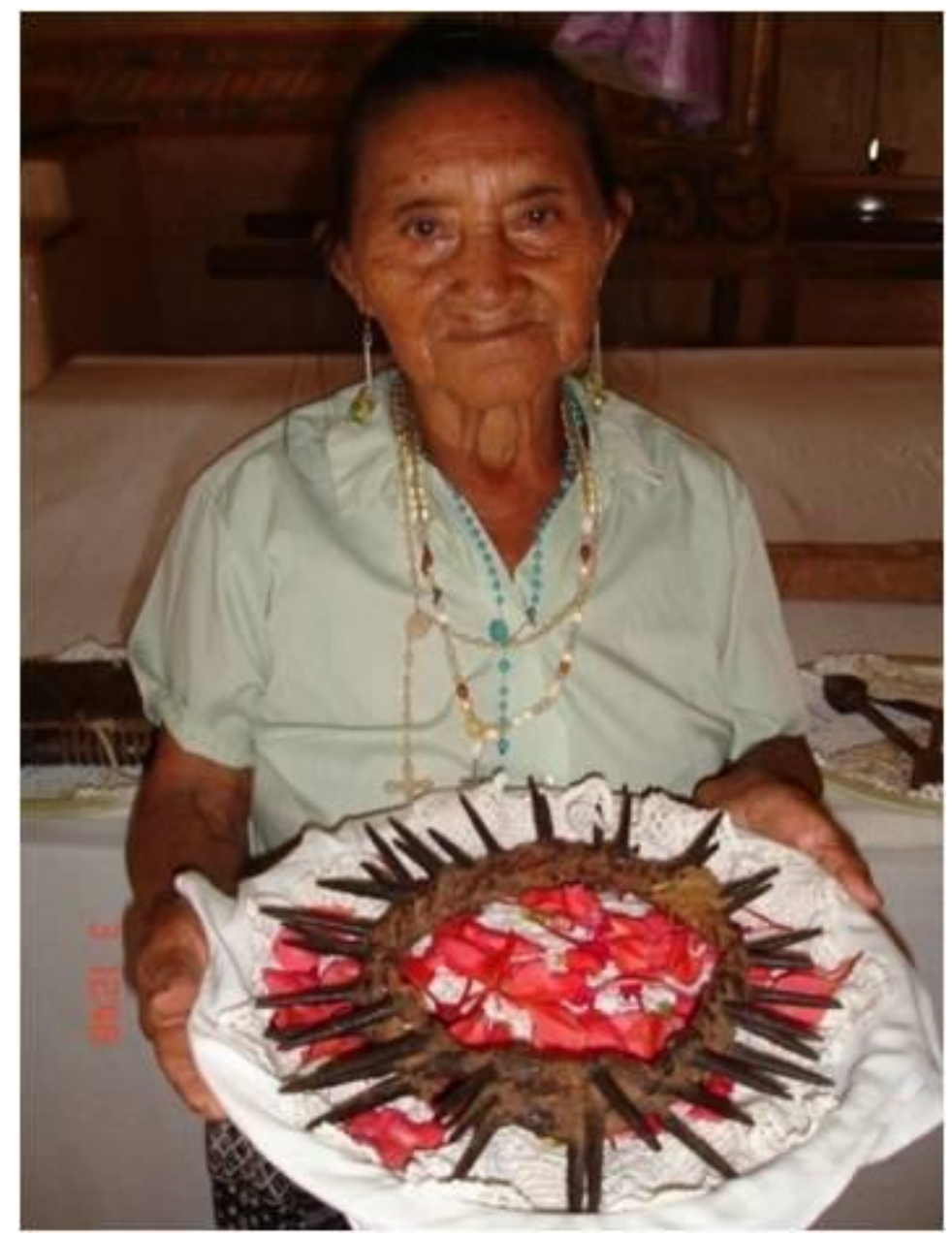

Imagem 2: Andréa Paticu Pachuri ${ }^{25}$ com a bandeja forrada com pano branco e coberta com outro bordado e a Coroa de espinhos retirada da cabeça de Jesus, depois de morto, na cruz na Sexta Feira da Paixão. Observe as flores vermelhas sob a coroa que lembram o sangue derramado de Cristo (Santa Ana de Velasco, 03/04/2010).

transculturação na antropologia, uma vez que a percepção mais apurada é que as culturas sempre foram dinâmicas.

${ }^{25}$ Esta senhora chiquitana vivia na comunidade chiquitana brasileira Osbi, que depois foi batizada Santa Aparecida, e acompanhou a Romaria de Santa Ana até a Bolívia, em 1970, casou-se por lá e vive em Santa Ana atualmente (ver seu sobrenome associado à planta Patchuli na nota 14).

Espaço Ameríndio, Porto Alegre, v. 6, n. 2, p. 137-177, jul./dez. 2012. 
A polêmica entre Sahlins (1995) e Obeyesekere (1997) levou à reflexão a respeito da assimilação dos conquistadores como divindades, o que não é o caso chiquitano: trata-se de uma ideia pervasiva na história colonial narrada pelos europeus, mas não estranha aos nativos. Tampouco se trata de alternância religiosa dos Chiquitanos. O que foi lido como a "inconstância da alma selvagem" 26 mostra que a separação humano/divino, para os Chiquitanos, não estaria na ordem do Ser, mas do acontecer. Os demiurgos eram grandes xamãs-pajés do passado revividos, mortais e imortais, homens e divinos.

Estas associações seriam sobrevivência dos mitos, ou seja, na interpretação dos antropólogos, estes querem perpetuar o "velho modelo mítico da mentalidade primitiva". Porém não é este o caso, acreditam os Chiquitanos que, com rezas, a alma do morto pode ser revivificada para viver junto de Deus porque os Santos já estão ressuscitados e intercedem pelos devotos.

As orientações religiosas dos jesuítas narravam que os seres humanos eram capazes de ressuscitar e a cosmologia chiquitana concebia esta possibilidade também. As experiências históricas concretas de cura com remédios, a oferta de presentes e a atuação dos jesuítas como xamãs, principalmente no atendimento aos doentes nas Missões, reforçaram o lugar de destaque dos "de fora" e esta crença na imortalidade da alma.

Aquele que fabrica os machados, os espelhos e outros instrumentos musicais, o que ensinava a tocar alguns instrumentos que eles não conheciam e queriam aprender, a esculpir a madeira, a construir as igrejas e outras atividades estaria mais próximo dos deuses, teria poder de transformar seus corpos também. As coisas recebidas como presentes eram "signos dos poderes da exterioridade, que cumpria capturar, incorporar e fazer circular" (VIVEIROS DE CASTRO, 2000 , p. 41). Assim o inimigo conquistado ensinava a técnica da

\footnotetext{
${ }^{26}$ Eduardo Viveiros de Castro (2002), para ilustrar o labor do missionário, utiliza a alegoria da estátua de mármore e de murta. A primeira é mais difícil de fazer pela resistência que oferece; e alguns tipos de madeira são fáceis de esculpir, como a murta, se molda ao corte das cercas vivas, porém os indígenas seriam "inconstantes".
} 
ALOIR PACINI - Um perspectivismo ameríndio e a cosmologia anímica chiquitana

fabricação dos objetos e como tocá-los, e os Chiquitanos se aplicam em aprender as técnicas dos jesuítas 27.

As cidades-santuários chiquitanas produzem uma ideia de civilidade dos "brancos" que passaram aos Chiquitanos, pois estes aprenderam a produzir objetos que passaram a identificá-los. Como inimigos familiarizados provedores de bens materiais nas Missões, os jesuítas se tornaram também inimigos oníricos, provedores de bens imateriais e senhores da ciência xamânica de produção dos bens e dos rituais nas igrejas que aconteciam com a presença jesuítica.

A introdução de instrumentos de metal tornou mais fácil a produção das esculturas, das pinturas, ou seja, das grandes igrejas, e o aumento da produção agropecuária, o que levou à transformação das relações de produção e o envolvimento intenso dos Chiquitanos em cada cidade-santuário, por causa do bem-estar que a abundância alimentar permitia, principalmente nas festas patronais, quando é desmedida a abundância de carne, de chicha e de alegria.

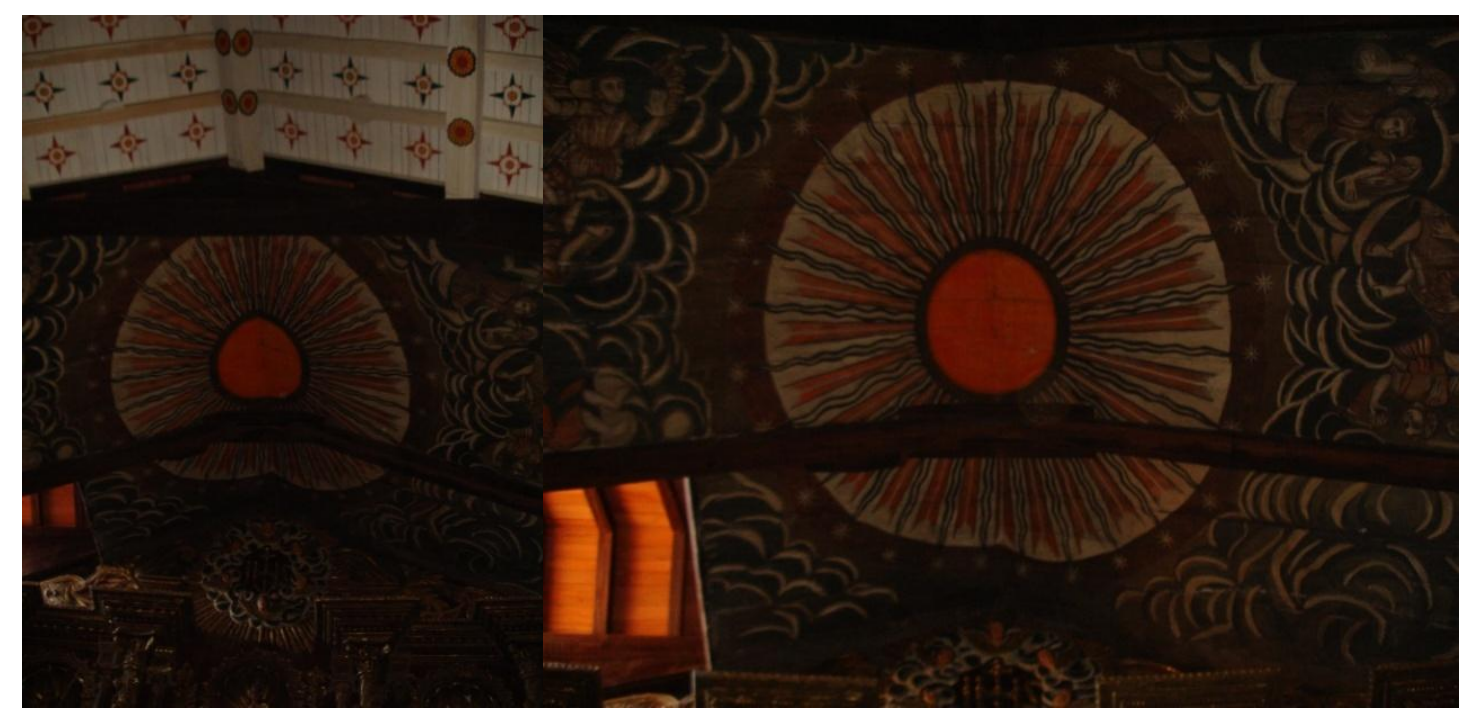

Imagem 3: Observe o sistema de iluminação no teto sobre o altar da igreja San Miguel, que aponta para a pintura do Coração de Jesus branco com os raios vindos do outro coração de Jesus que está no centro, isso na perspectiva do público. Quanto mais próximo e junto do altar, a figura se torna mais redonda e menos parece as duas figuras do Coração de Jesus; aparece mais o sol brilhoso, as estrelas em volta e as nuvens

\footnotetext{
${ }^{27}$ Em 1504, o capitão Paulmier de Gonneville levou o filho do chefe Carijó Arosca para a França. Assim como os colonizadores desejavam o ouro, a prata e as pedras preciosas em geral, o sonho de Arosca era aprender artilharia como também a fazer espelhos, facas, machados e tudo o que viam e admiravam dos "brancos" para dominar seus inimigos. "Os objetos escassos e desejados são sujeitos - princípios de existência e capacidades subjetivas -, não insumos ou bens de consumo. O espaço político e as relações interlocais erguem-se menos sobre a troca de utilidades do que sobre o fluxo de corpos e bens imateriais, operado pelo casamento e pela guerra" (FAUSTO, 2001, p. 597).
}

Espaço Ameríndio, Porto Alegre, v. 6, n. 2, p. 137-177, jul./dez. 2012. 
com anjos, abaixo o símbolo ${ }^{28}$ da Eucaristia, que também se tornou o símbolo da Companhia de Jesus (Fotos de 30 de julho de 2011).

Os Chiquitanos aplicaram-se na expansão de sua eficácia simbólica na relação com os jesuítas e os "deuses" cristãos nas imagens dos Santos, assim a perspectiva cosmológica dos Chiquitanos foi associada ao cristianismo. As ferramentas foram incorporadas a um modo de produção preexistente voltado para a produção de pessoas e das próprias unidades sociais. Os brancos em geral e os jesuítas em particular foram também associados difusamente à antropofagia, afirmando-se "comedores de gente" nos rituais da Missa de modo especial.

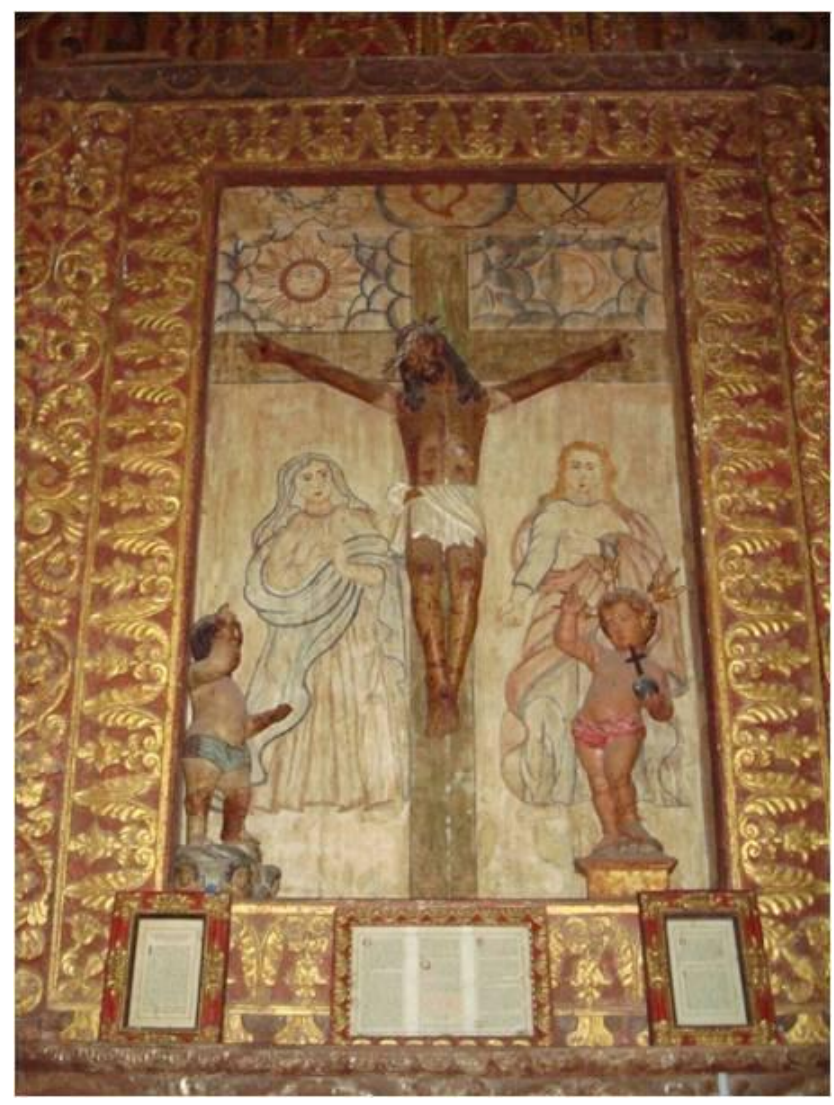

Imagem 4: Retablo do Cristo Crucificado na sacristia da igreja San Rafael associado com as pinturas do sol e da lua na altura da cruz; bem no alto o Sagrado Coração, de um lado os três cravos e no outro a coroa de espinhos como os Chiquitanos colocam na Sexta-feira Santa. Abaixo estão duas imagens do Menino Jesus, claramente fora do lugar original (foto de 01/01/2007).

\footnotetext{
${ }^{28} \mathrm{O}$ conceito de símbolo está relacionado com a unidade do "significado, usado para qualquer objeto, ato, acontecimento, qualidade ou relação que serve como vínculo a uma concepção" (GEERTZ, 1978, p. 105).
}

Espaço Ameríndio, Porto Alegre, v. 6, n. 2, p. 137-177, jul./dez. 2012. 
A Virgem Maria é associada à lua; e as fases da lua, à menstruação das mulheres. Jesus é associado ao sol e do seu Sagrado Coração desce a água do Portal do Encantado e da Serra do Barbicho, pois a pregação dos jesuítas procurava traduzir para imagens concretas sua cosmologia.

Este hombre (por abreviar) al fin les dixo a las gentes: para que entendáis, y veáis, que yo soy diferente de vosotros, y que mi padre es arriba, aora lo veréis, y elebándose en el ayre a vista de todos, de repente se combirtió en Sol, y subió a las Alturas, donde aora le vemos, lamentándose sus parientes y amigos de su ausencia (CABALLERO apud SANZ, 1933, p. 22).

No texto, o missionário critica esta postura maniqueísta de "que el Sol es hombre luminoso" num processo de aproximação de opostos. Don Lucho disse-me no dia 31-07-2011 que as imagens dos Santos possuem um oco dentro com uma portinha (ventanilla). Ali dentro colocavam o nome da imagem, alguns dados da pessoa que a talhou. Isso servia para tornar mais leve a imagem nas procissões. Perguntei se ali guardavam também algum tesouro, mas ele disse que isso é história del pueblo, não havia este tipo de tesouro para guardar.

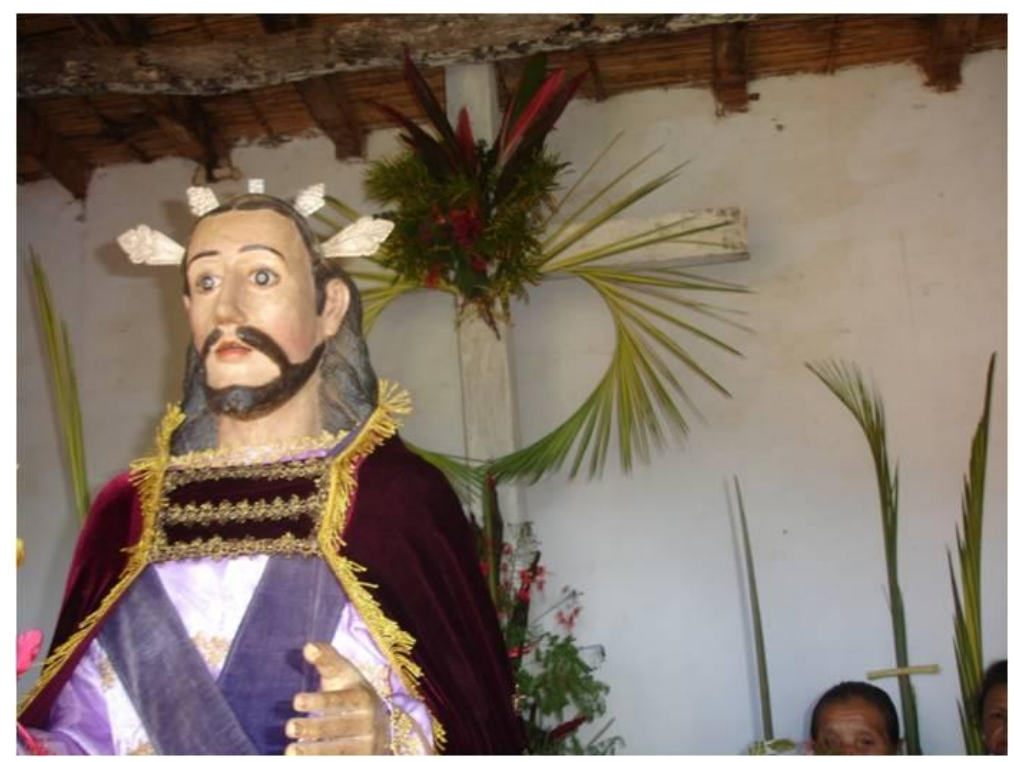

Imagem 5: Domingo de Ramos de 2011, foto de Jesus em Betânia (Santa Ana), montado num burrico com um ramo enfeitado com flores na mão direita. No fundo, junto à cruz, uma figura do Coração de Jesus feito com folha do broto de acori (mutacu $)^{29}$.

\footnotetext{
${ }^{29}$ Aqui nós vemos que a folha do mutacu ou acori é usada para aclamar Jesus na entrada triunfal em Jerusalém (procissão que sai de Betânia no Domingo de Ramos) e o coração de Jesus foi feito dobrando
}

Espaço Ameríndio, Porto Alegre, v. 6, n. 2, p. 137-177, jul./dez. 2012. 
Os Chiquitanos circulam sempre da direita para a esquerda nos seus rituais. A etnografia fez-me ver os movimentos centrífugos e centrípetos (FAUSTO, 2001, p. 533-544) presentes entre os Chiquitanos por causa de sua mescla étnica. A predação familiarizante, na perspectiva dos Chiquitanos, seria uma troca do Santo com seu devoto, uma transmissão das bênçãos dos Santos para os devotos fiéis, numa relação que parece mais vertical nas igrejas e uma relação mais horizontal quando estes Santos são levados para os oratórios nas casas. São bens e atributos nos dois modos de reprodução social de pessoas como mecanismo de reprodução generalizada da sociedade. Existem gradações no envolvimento das pessoas nos rituais, que seriam forças centrípetas nos mecanismos de introdução de nomes de Santos "estrangeiros" para os que forem batizados. "Um nome condensa um fluxo de relações que ele ao mesmo tempo representa e realiza" (FAUSTO, 2001, p. 536).

Nos sistemas centrípetos, a esfera de circulação horizontal e vertical de bens simbólicos se amplia no interior do sistema, ocupando o lugar do consumo produtivo por meio da predação (FAUSTO, 2001, p. 534). Assim os Chiquitanos incorporaram grupos inimigos enquanto etnias distintas e tornaram o sistema multilinguístico e multiétnico na Chiquitania uma realidade. Assim delimitado, locais de diferentes formações sociais faziam fronteira com esta unidade e diversidade étnico-cultural.

estas folhas de mutacu. Na quarta-feira de cinzas estas folhas que foram bentas neste dia e que não foram queimadas para acalmar as tempestades são queimadas para fazer as cinzas que serão colocadas nas cabeças dos fiéis. As cinzas que sobrarem serão colocadas no buraco feito dentro da igreja de Santa Ana, onde é plantada a cruz na Sexta-feira Santa. Depois que Jesus é descido da cruz e tirada a cruz deste local em frente do altar, as pessoas recolhem esta cinza e a levam para jogar nos seus chacos (roças) e ali fecundar a terra-mãe. Este mesmo mutacu ou acori é uma chiquitana que foi encantada pela sua mãe pajé quando beijou o bibosi-nobiosürch ou a figueira. 


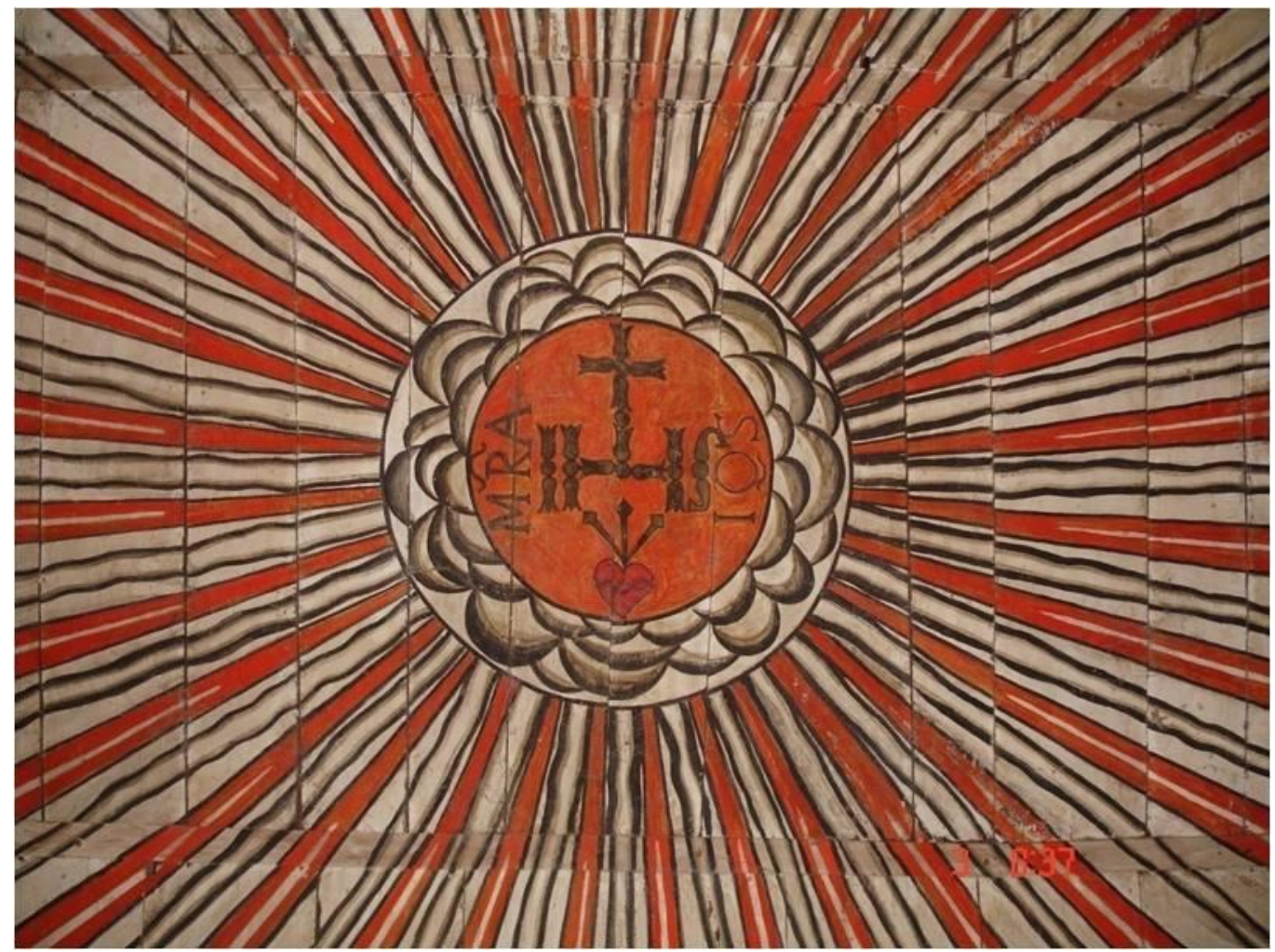

Imagem 6: Imagem sincrética anônima. Pintura do sol e, no centro, o símbolo da Eucaristia, que também se tornou o símbolo da Companhia de Jesus, como que dentro do sol; e o nome Maria e a figura do Coração de Jesus com a coroa de espinhos e os três cravos (Foto do teto da sacristia da igreja San Miguel, 3 de Maio de 2010, festa da Santa Cruz).

\section{Relação devota com os Santos patronos}

... para el chiquitano, la estatua del santo no sólo es una representación, sino el verdadero santo; así se explica que los indios se encariñaran con toda el alma hasta de las estatuas muy viejas y defectuosas y hasta mutiladas, y las prefieran a las nuevas, que según nuestro criterio son mucho más hermosas o por lo menos más dignas (PADRE OTHNER apud JUSTINIANO, 2004, p. 339).

O repicar dos sinos marca o ciclo temporal dos pueblos missionales, e suas celebrações são acompanhadas com formas distintas de fazer soar a música com as campanas. Em Santa Ana, até hoje, o horário da escola municipal é marcado por três toques compassados no sino da igreja. O toque del alba, às três horas da 
madrugada, possui 7 melodias e é acompanhado por toques de caixa e flauta. Os rituais são anunciados com o sino.

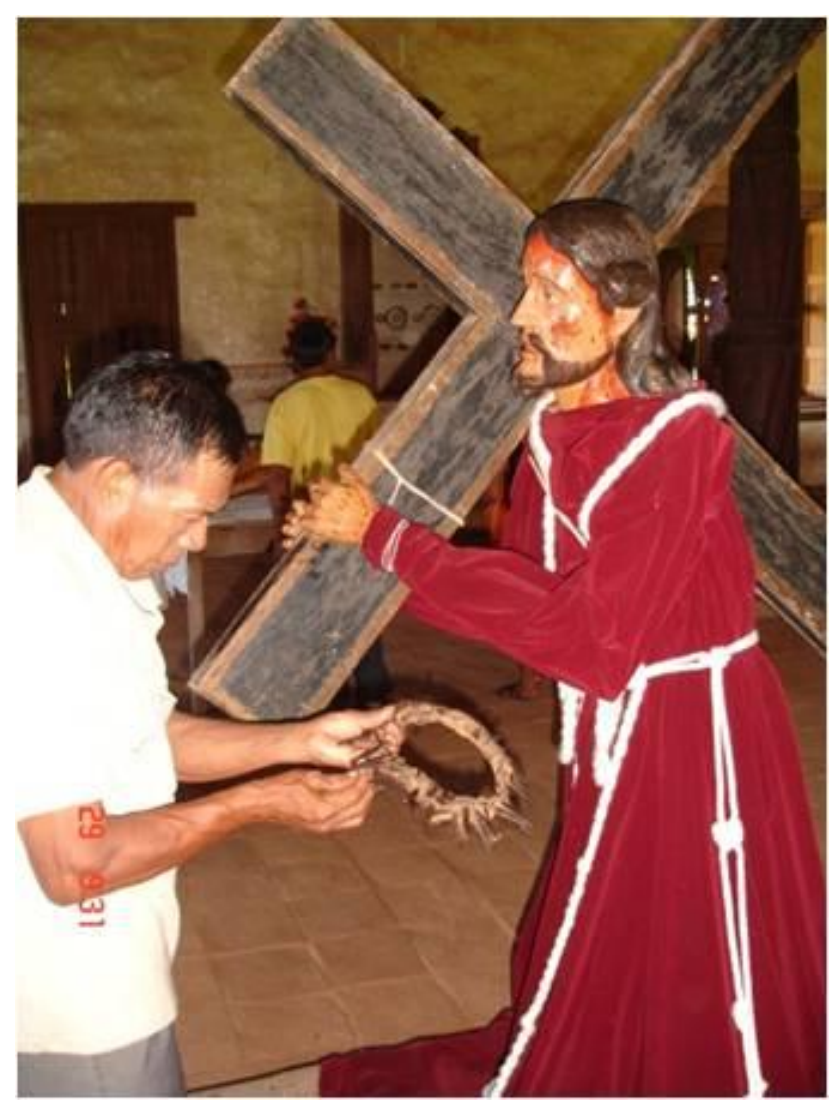

Imagem 7: Foto do Senhor dos Passos que sai nas procissões da via-crucis durante a Quaresma e na Quarta-Feira Santa, em Santa Ana de Velasco. A coroa de espinhos está sendo limpa por um dos apóstolos para colocar em sua cabeça (29/03/2010).

No tempo dos jesuítas, havia a escola para aprender a escritura e leitura do chiquitano e a escola para a música e o canto, a escultura e a pintura e as artes cênicas. O elemento didático das artes para a evangelização é visível nos documentos, nos monumentos patrimoniais deixados em Chiquitos e na memória dos Chiquitanos. O modo de se relacionar dos Chiquitanos com as imagens dos Santos é típico, ou melhor, a relação é direta com o Santo presente na imagem, como registrou Roberto A. Balza, o que foi transcrito por Justiniano na epígrafe acima. O Padre Othner, apesar deste não ter compreendido a fineza da fé dos Chiquitanos e nem ter chegado a perceber o valor acrescentado das histórias vividas com as imagens de alguns Santos, contudo, soube perceber uma originalidade desta oração: "Ios indios se 
encariñaran con toda el alma hasta de las estatuas muy viejas y defectuosas y hasta mutiladas, y las prefieran a las nuevas" (PADRE OTHNER apud JUSTINIANO, 2004, p. 339).

Pelo que pude observar entre os Chiquitanos, não se trata de uma relação de idolatria para com as imagens, como alguns "crentes" que os desprezam procuram imputá-los. A relação com o transcendente se dá a partir de "portais", as imagens são espécies de portais de entrada numa relação de grande intimidade, uma mediação que dá acesso a este mundo dos Santos (céus), às vezes associados aos encantados (terra). A imagem de um portal que separa o mundo humano propriamente dito e o mundo dos encantados faz com que os Santos seriam seres do mundo dos céus que podem vir para a terra porque sabe onde está o portal e como ir e vir para regalar o que o devoto necessita. Neste sentido, existem vários tabus para que os humanos não queiram atravessar este portal também, pois estes contatos levam à "morte". Na Semana Santa, em preparação para a Páscoa, por cima das cruzes são colocados arcos ornamentados com folha de pototó (são-gonçalo ou gonçalero) para indicar que a cruz é a chave do portal que permite chegar ao outro mundo possível.

Vejo aí uma dinâmica centrífuga que adquire do exterior o estoque de nomes, em geral de Santos, maneira de domínio da Patrona Santa Ana sobre seu devoto que é posto em circulação. Não é um acaso a pessoa ser chamada Santiago, Maria, Miguel, Ana, Pedro etc. Cada aldeia é um microcosmo mais ou menos autônomo que captura e incorpora membros isolados de grupos externos dissolvendo suas identidades no sistema recortado das diferenças internas. Penso que os Chiquitanos, utilizando este conjunto de nomes de Santos para colocarem nos seus filhos e comprometê-los de alguma forma com a devoção ao Santo onomástico é um fator especial para a importância que ganhou o lugar dos Santos na Chiquitania, na linguagem de Carlos Fausto, na relação de senhor-xerimbabo, os Chiquitanos se sentem vinculados e acompanhados. Como as pessoas, também os lugares são cristianizados ao serem nominadas com os nomes dos Santos 30 e isso

\footnotetext{
${ }^{30}$ Engana-se grandemente quem pensa que esta forma de toponímia é menos indígena do que quando existe um nome na língua indígena para os acidentes geográficos, rios e montanhas, segundo o gosto da maioria dos antropólogos e indigenistas.
}

Espaço Ameríndio, Porto Alegre, v. 6, n. 2, p. 137-177, jul./dez. 2012. 
chama a atenção dos que chegam na Chiquitania, especialmente os novos colonizadores Aymara que descem dos Andes impulsionados pela política do presidente Evo Morales.

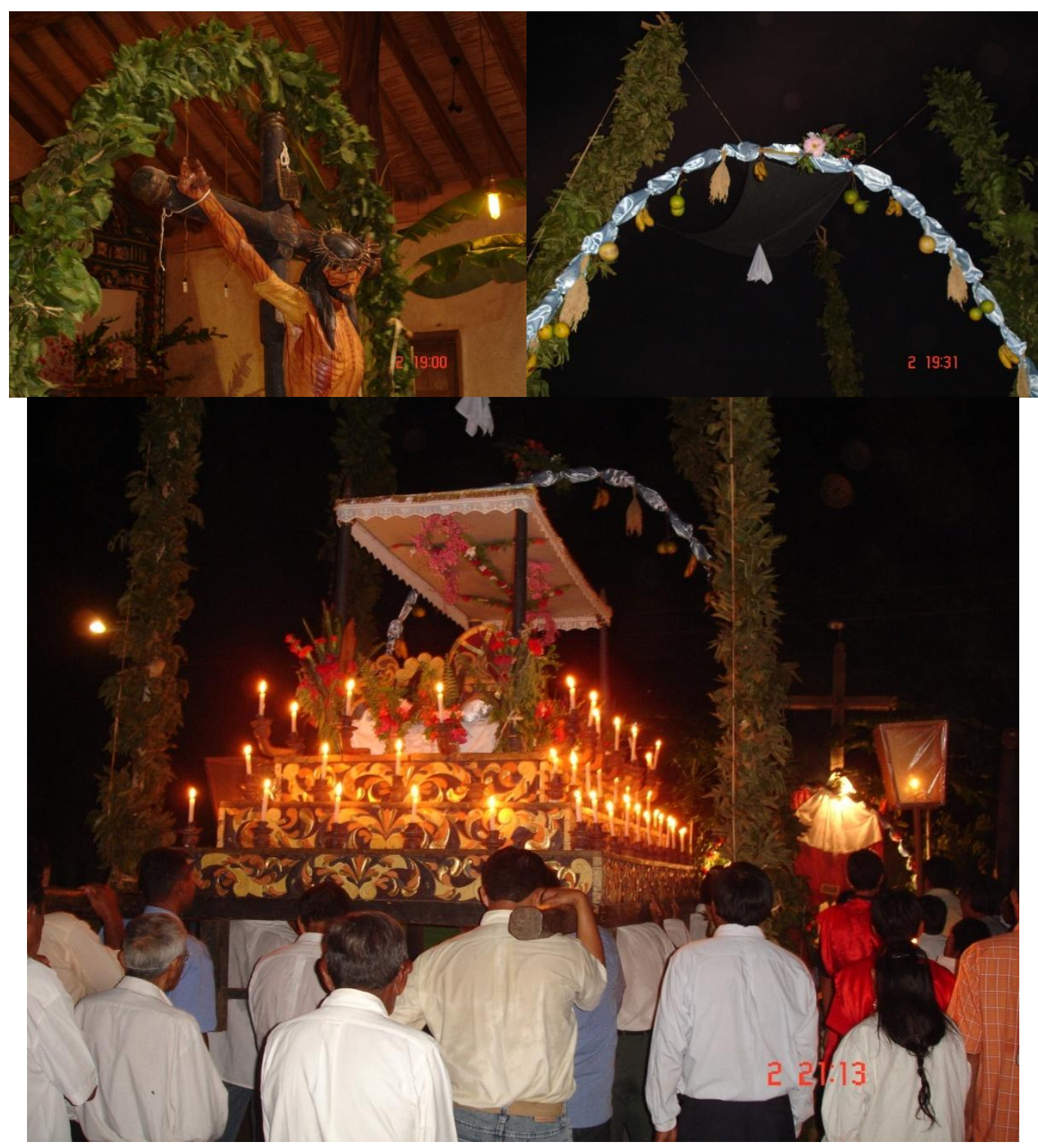

Imagem 8: Cenas da Sexta-feira Santa em Santa Ana, dia 2 de abril de 2010. Arcos dentro da igreja antes do descimento de Jesus da cruz, locais de oração nos quatro cantos da praça e a procissão de Jesus no sepulcro com as 72 velas acesas.

A perspectiva da predação não elimina a alteridade, ao contrário, constrói uma relação entre opostos e os harmonizam. A alteridade entre 
predador (jaguar ${ }^{31}$ e guerreiro) e presa fundamenta o processo produtivo no modo indígena estudado por Fausto como entre os Chiquitanos.

A predação é o modo mais acabado de determinação do ponto de vista na relação entre entes dotados de agência e intenção. É por meio dela que se determina qual dos sujeitos é capaz de impor sua própria perspectiva ao outro (FAUSTO, 2001, p. 538).

A subjugação na predação determina quem possui o ponto de vista numa relação com a vítima no caso da guerra; e do espírito dos animais no caso do ritual xamânico. O que está em jogo para Fausto é o "movimento de conversão da predação em familiarização para a produção de novos sujeitos: familiarização do outro-humano (subjetividade de inimigos) e do outro-não humano (subjetividades nãohumanas)" (FAUSTO, 2001, p. 539), segundo o esquema seguinte: afim consanguíneo (parentesco); inimigo - espírito da vítima (guerra); presa espírito familiar (xamanismo).

Assim a relação do devoto com o Santo torna-se familiar pela adoção deste que veio "de fora" e tem por fim alcançar o mundo espiritual, necessário para a "salvação" do devoto, através de um compromisso de fidelidade em realizar a sua festa, o que gera um bemestar na comunidade, onde todos comem e bebem à vontade, e se reproduz esta sociedade chiquitana através destes rituais extremamente densos.

Ao mobilizar a perspectiva do outro em proveito da reprodução dos próprios Chiquitanos, a suprassunção (aufhebung, conforme a dialética de Hegel), mais que a supressão, indica a dialética de controle em que o devoto busca se transmutar no Santo. Ao mesmo tempo em que a devoção controla a subjetividade do devoto, também reproduz a vida da família e da comunidade ou aldeia ou pueblo. O corpo é o suporte material para inscrever capacidades e representar relações

\footnotetext{
31“"A figura prototípica da regressão à natureza, o jaguar, aparecia associado à condição mesma de deuses e xamãs" (FAUSTO, 2001, p. 510), algo semelhante à perspectiva chiquitana em que contam histórias de vários Chiquitanos que se transformaram em jaguares, tigres, onças, antas, jegues, burros, porco do mato e outros animais por encantamento dos donos destes animais, chamados hitchis; e mesmo a xamã mencionada anteriormente que encantou sua filha para se tornar uma acori e seu enamorado em figueira, que se transformava em onça.
}

Espaço Ameríndio, Porto Alegre, v. 6, n. 2, p. 137-177, jul./dez. 2012. 
quando mascarado, tatuado, ornamentado, fabricado, esculpido, pintado ou ainda esquartejado e predado:

... a corporalidade é um operador fundamental: a apropriação das capacidades do jaguar implica vestir sua pele [...] O modelo canibal de apropriação de subjetividades reencontra, desse modo, o tema da centralidade do idioma corporal não apenas pela ponta de consumo - isto é, pela destruição de corpos outros mas pela ponta da construção de novos sujeitos, de seus corpos e capacidades (FAUSTO, 2001, p. 541).

Carlos Fausto, ao distinguir o momento da predação e da familiarização no movimento da predação ontológica, introduz a negatividade da predação, a assimetria da relação na noção de troca de pontos de vista para suprassumir os elementos da dialética, afirmando também a condição subjetiva do que foi predado.

Os Chiquitanos tendem a olhar o mundo que os cerca segundo os critérios próprios de sua cultura, que, para o observador externo, pode parecer pouco prático. Os esforços para fazer a festa e conseguir alimentação abundante são desmedidos e geralmente esgotam as finanças dos festeiros. Porém saem da festa realizados quando tudo deu certo. Mas não é só o conhecimento da natureza e dos hitchis que a movem, é a forma de ter uma comunicação com estas "divindades" que fazem parte do seu mundo social que interessa. A inter-relação dos diferentes domínios é importante para dar conta da complexidade da perspectiva indígena. Por isso, é importante ver os corpos transformados, uma humanidade ou sociabilidade mais alargada, flexível para outros seres. Diferentes corpos mostram os diferentes escafandros para a agency dos objetos. A Antropologia pós-social tem o serviço de relativizar-se a si mesma e aos processos cognitivos diferenciados, enquanto pele social, permite ver a agência dos Santos na Chiquitania, identificados nas suas imagens para formar uma etnia "civilizada".

Os Chiquitanos vivem em fronteiras que não são fixas nem rígidas, a perspectiva é fluida como um rio que corre, uma estrada ou caminho vicinal que funciona como "cabriteira", ou mesmo estradas oficiais e trens com vagões que se movem. A dicotomia do sagrado e do profano já foi desconstruída, pois trata-se de leitura inadequada da 
realidade chiquitana que observa tudo com ar de sagrado, e expressa isso no cotidiano e nos momentos rituais dentro de uma linguagem artística.

O gêmeo ou a imitação de uma dada imagem (dos Santos) é questão de diferença, não de identidade, pois até quando nascem gêmeos entre os Chiquitanos, geralmente um deles é criado por outra família para diferenciar-se. Cada obra de arte é única para eles, não existe simetria perfeita ou produção em série, por isso pode haver complementaridade entre etnias, entretenimentos entre "civilizados" neste tecido da vida em sociedade. As imagens possuem uma linguagem espiritual, o que separa o dentro e o fora, o humano e o divino que cobre com a mesma pele cultural a identidade e é associada à roupa cultural de personagens de outros mundos desconhecidos, mas que pareciam aos usados pelos jesuítas nos rituais. Incorporar conhecimentos é mais que acumular dados, é parte da predação do outro diferente. No corpo dos objetos produzidos é que se inscrevem estas artes como formas de conhecimento e familiarização do de fora. Com este texto quero ir além da semântica dos significados (LUX VIDAL, 1992) para encontrar a lógica da complementaridade, da fertilidade do mundo ontológico da identidade chiquitana atual, que soube sobreviver neste mundo da colonização que é tão hostil a eles.

O processo artístico e estético das obras de arte chiquitanas, que "está ancorado na matriz da ação humana" (VIDAL e LOPES DA SILVA, 1992, p. 280), permite ao antropólogo compreender seu conteúdo simbólico. A emoção estética e cognição técnica têm a ver com a experiência que pode ser apreendida e transmitida. As artes chiquitanas são manifestações públicas de talentos. Esculpir, pintar, trançar cestos, fazer potes, tocar, cantar e dançar, estes atos humanos com inspiração divina possuem seu contexto cultural. Para compreender seu simbolismo, temos que compreender esta sociedade indígena nas cidades santuários, que significa muito mais do que conseguem representar na sua arte. Os trabalhos artísticos possuem uma significação elaborada no local, inseparável do contexto e dos meios socioculturais que os permitem. O design une a forma e o contexto no simbolismo visual estético-artístico que é articulado com os sistemas socioculturais e religioso-cosmológicos nos quais os Chiquitanos estão 
inseridos hoje, mesclados com o cristianismo, que não precisa ser expurgado para que sejam indígenas. O significado e o uso podem ser apreendidos observando as reações das pessoas (dos artistas, dos Chiquitanos e dos turistas) em relação à obra de arte e o significado que decorre da posição da obra em relação a outros símbolos na estrutura de organização de determinado pueblo:

... a antropologia aborda as manifestações artísticas
preocupada em compreender a natureza mesma da
experiência estética e a capacidade de comunicação da
obra de arte, que nasce do encontro de estilos e
concepções coletivas e culturalmente construídos e
aceitos, mas trabalhadas e reelaboradas de modo único
por artistas que, individualmente, nela colocam sua
técnica, sua sensibilidade e sua habilidade criadora
(VIDAL e LOPES DA SILVA, 1992, p. 283).

A corporalidade na etnologia brasileira tornou-se referência para a compreensão das sociedades indígenas. Para Antony Seeger, Roberto Da Matta e Eduardo Viveiros de Castro (1987), os corpos com seus adornos (grafismos e ornamentos) são matrizes de símbolos e objetos de pensamento quando criados, decorados, transformados ou predados. Porém o aspecto que estou especificamente apresentando aqui é que a escultura de seres humanos na "arte sacra" chiquitana representa os Santos nas igrejas e nas casas e ali estes se tornam familiares, se tornam parte de sua civilização.

$\mathrm{Na}$ etnologia brasileira, as artes gráficas e a ornamentação corporal são, ao que tudo indica, as mais estudadas, se tomadas em comparação, por exemplo, com os estudos existentes sobre escultura, máscaras, música, dança e poesia. Isso se deve principalmente à primazia dada às manifestações visuais e à influência dos estudos sobre cultura material, que inclui a plumária, a cestaria e a cerâmica (VIDAL e LOPES DA SILVA, 1992, p. 283).

A arte gráfica, as esculturas e pinturas expressam significados socioculturais. Algo do indizível ou do latente na vida cotidiana e que está na reflexão coletiva torna-se visível através das artes. Por isso presto atenção dobrada no que é dito e mostrado nas artes, como é dito, para quem é dito. Isso modifica a mensagem gráfica na sua relação 
com outras esferas da vida social e cósmica. A comparação no tempo e no espaço permite identificar estilos próprios de arte de cada etnia, algo que os Chiquitanos identificam apesar dos empréstimos tradicionais de padrões artísticos de outras etnias ou elaborações novas.

Alguns representam na sua arte gráfica as entidades sobrenaturais e conceitos cosmológicos mais amplos. As artes possuem propriedades espirituais que atuam na transformação do corpo humano (cf. pinturas waiãpi; a cestaria wayana; os wasain'du - coisas, enfeites - mamaindê; a cerâmica asurini, as bonecas karajá etc.), e um pouco de cada uma destas concepções está presente nas imagens de Santos para os Chiquitanos. Assim cada sociedade se expressa através das artes que produz e nenhuma deve ser desqualificada.

Os significados culturais expressos pela iconografia
indígena não se restringem, portanto, a informações
relativas à sociedade, sua morfologia e a identificação
de status e estados de seus membros. Preocupações de
ordem filosófica ampla, relativas à própria definição de
humanidade, seu lugar no cosmo e os modos corretos
ou desejados de sua articulação aos outros domínios
que compõem o universo são também objetos de
representação por meio de imagens gráficas (VIDAL e
LOPES DA SILVA, 1992, p. 287).

$\mathrm{Na}$ grande variedade de material utilizado, a madeira para esculpir, a argila para moldar, as tintas para pintar, as palhas para trançar e outros materiais foram instrumentos que os Chiquitanos escolheram para produzir seus potes, chapéus e suas esculturas, alguns objetos de aporte mais autóctone que outros por causa das ferramentas trazidas pelos missionários, que eram mais adequadas para a escultura, por exemplo. Hoje, cada vez mais, o papel está presente nesta dinâmica das culturas indígenas onde as estampas de pintura corporal ou dos Santos são formulados e os símbolos tradicionais são recriados. As pinturas em papéis motivadas pela escola são obras de arte facilitadas pelos estudantes. Os artefatos

ressaltam os significados simbólicos (sociais, cosmológicos, individuais) das artes gráficas indígenas em contextos atuais. [...] Cada povo tem um nome e uma produção específica e os artistas também possuem 
ALOIR PACINI - Um perspectivismo ameríndio e a cosmologia anímica chiquitana

nomes e uma identidade pessoal definida (VIDAL e LOPES, 1992, p. 290).

No trabalho de campo, não vi grande diferença no material utilizado para que a relação dos devotos fosse melhor ou mais intensa. Igualmente o substrato é tratado como o próprio Santo, no caso de ser uma estampa de São Miguel, uma imagem do Santo esculpida na madeira de cedro ou uma cruz de aroeira. Aproxima-se com a mão direita até tocar na estampa ou imagem ou cruz para fazer sobre si o sinal da cruz e apropriar-se assim da "santidade" em forma de bênção. Esta bandeira de São Miguel com a sua estampa ou a imagem de Santa Ana na Romaria passa de casa em casa nas aldeias e um lugar na casa é preparado para recebê-la: uma mesa com toalha branca. Ali as outras imagens de Santos da casa são colocadas para receberem o visitante. No momento em que a bandeira ou a imagem chega, sob cantos e rezas, esta é levada para os diferentes cômodos da casa para abençoar e afastar os males.

A cultura como sistema simbólico permite atribuir significados à experiência cotidiana e formular concepções que colocam ordem ao mundo vivido de forma dinâmica (cultural variation ${ }^{32}$ ). Por isso a repetição associada à variação, a tradição à inovação está ligada à ação dos indivíduos na história da criação e recriação cultural de cada etnia. Os Chiquitanos expressam sua identidade étnica diferenciada nos seus traços artísticos, no contexto de relação com as sociedades nacionais do Brasil e da Bolívia. Os devotos de um Santo como o pueblo de Santa Ana também formam um corpo e são uma representação simbólica que organiza as relações entre pessoas e famílias, linhagens e grupos rituais da sociedade chiquitana.

A relação de devoção acontece aparentemente por escolha pessoal, mas, olhando com mais cuidado, vemos que em geral as famílias ou linhagens possuem seus Santos de devoção relacionados às histórias das aldeias ou pueblos de origem. Para marcar esta origem, os nomes das pessoas estão também relacionados. Por exemplo, Dona

\footnotetext{
${ }^{32}$ F. Barth usou esta expressão em 1987, ou seja, as culturas são anteriores à fixação da escrita, sempre "a partir de um repertório comum, de um patrimônio cultural coletivamente construído, compartilhado, compreendido. Seria, portando, própria à oralidade, a capacidade da fusão do passado e do presente em um discurso único, momentâneo e fugaz, mas suficientemente ancorado em uma tradição cultural para ser reconhecido como verdadeiro e significativo" (VIDAL e LOPES DA SILVA, 1992, p. 292-293).
} 
Micaela, cujos antepassados vieram de San Miguel, fez a festa de San Miguel na sua casa, em 2006, e possui um filho chamado Miguel que fica com ela ${ }^{33}$. De alguma forma, os nomes dados para as pessoas já direcionam suas devoções. Santa Ana possui sua região de influência na fronteira do Brasil, o que impressiona, como San Rafael e San Ignacio; dentro dos próprios pueblos e para além deles, muitos são os que recebem estes nomes no batismo.

Lux Vidal e Regina P. Müller (1987) escreveram uma obra importante a respeito dos adornos como material visual e sistemas autônomos de comunicação, uma porta de entrada para compreender a arte chiquitana. Regina Müller usa o código simbólico relacionado com a organização social xavante. Esse código é uma roupagem na performance dos rituais. Com isso pensei na semiologia para isolar e identificar os elementos visuais ou unidades mínimas distintivas que permitem uma diferenciação e uma ornamentação do Santo para transmitir uma mensagem de civilização e percebi quão cuidadosos são os Chiquitanos ao se vestirem e ao vestirem os Santos padroeiros!

Alfred Gell (1992) observou que os objetos têm agência sobre as pessoas, objetificam as relações sociais a partir dos estudos que fez na Melanésia de Malinowski. Neste caso, o estatuto dos objetos está relacionado à noção de pessoa, ou seja, a estrutura social de Radcliffe Brown etnograficamente estaria marcada no corpo e nos objetos, nos Santos e suas imagens.

E aqui trago um elemento novo que parece-me conectar todos os aspectos já mencionados. As imagens de sereias dentro das igrejas de San Rafael e San Miguel relacionam a cosmologia chiquitana tradicional com a existência de seres sobrenaturais e/ou divinos dentro do universo chiquitano num espaço propriamente religioso católico, o que aumenta sua relevância.

O sistema de comunicação visual é uma linguagem, resultado de usos recorrentes no enfoque da tela social. Outro enfoque é o perspectivismo dos anos 80 e 90, no qual o corpo é visto enquanto agência para a transfiguração, ou seja, Terence Turner (1979), nos anos 80 , olhava para a arte enquanto pele-social, o palco social onde se

\footnotetext{
33 A emoção estética tanto de Micaela quanto de seu filho quando fomos com eles para as cidadessantuários na Bolívia é indescritível, chegaram até a ficar com falta de ar pela grandeza destes momentos.
} 
mostrava a identidade social e cultural dos povos indígenas. O sistema seria como um todo e os limites entre as classes sociais estariam na pele!

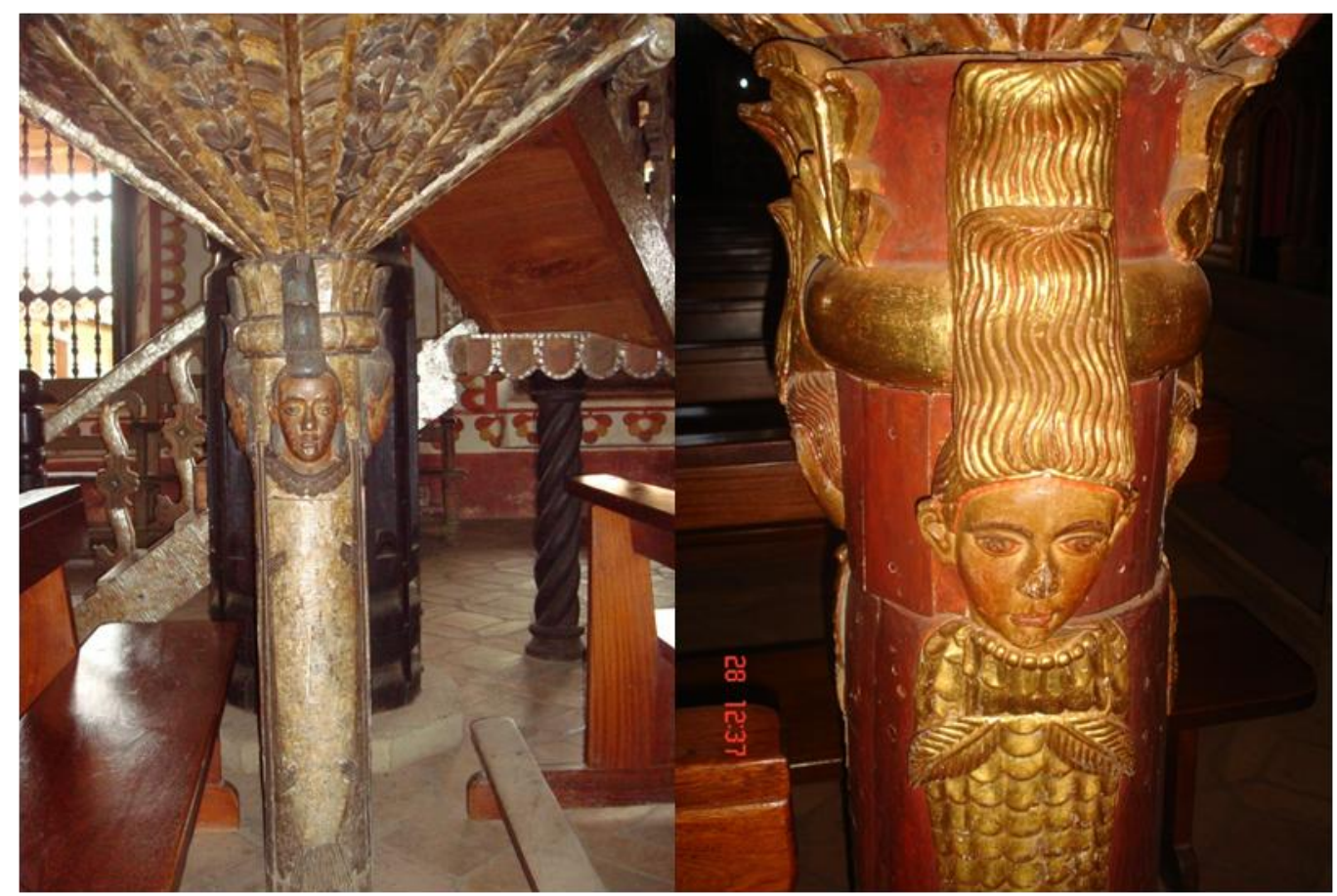

Imagem 9: Alto-relevo de hitchis de quatro sereias nos púlpitos das Igrejas de San Rafael (foto de 1/1/2007) e San Miguel (foto de 28/07/2010).

Observo aqui uma cosmologia anímica chiquitana relevante, pois os seres da natureza possuem alma, entram em relação uns com os outros, são pessoas como os seres humanos. Existe o hitchi dono do lago que controla os seres da água, outros hitchis nas árvores, nas serras que os identificam e cuidam como patronos. Este é um bom argumento que pode ser usado para demarcar o território tradicional chiquitano: os Chiquitanos pensam o território como extensão do seu corpo, humano e social. Pode-se compreender assim que as terras tradicionais são necessárias à sua sobrevivência física e cultural. Foi assim que se expandiu o sistema chiquitano que possui uma relação espiritual com os locais geográficos concretos e os outros seres vivos. $\mathrm{Na}$ frente da igreja de Santa Ana está gravado na madeira: 1755 Anaurti Tupar Zoipiakima Santa Ana 1997 (Bendito seja Deus e Nossa Mãe Santa Ana). Este espaço está demarcado e identificado dentro da cosmovisão chiquitana! 
Joana Miller (2007) explorou a possibilidade de descrever pessoas e espíritos como "coisas", uma inversão indicada no próprio discurso dos Mamaindê em particular e dos Nambikwara em geral, que veem os animais, os vegetais, o tucum e o algodão como espíritos, "matérias primas" com agência e não são simplesmente objetos, como tendemos a ver, ou seja, suas existências entram em relação como sujeitos para formar o colar.

Podemos assim dizer que os objetos possuem agência em diferentes modos culturais. Talvez Marcel Mauss (1974) falaria em "objeto social total", pois há uma relação próxima entre os corpos dos Santos e os corpos dos jesuítas vestidos como os corpos dos Santos e dos Chiquitanos que passaram a usar roupas também, uma interligação do cosmos numa cosmologia talvez animista. A relação fundamental anímica poderia ser observada em cada indivíduo com seu nome de Santo ou pela família que possui seu Santo onomástico ou padroeiro, com quem mantém relação de intimidade, de troca e intimidade. Cada Santo está presente em cada aldeia e pode estar em forma de vários exemplares. "Esta reduplicação de sistema de conjunto e esta multiplicação de elementos singulares corresponde à dimensão social do panteón" (AUGÉ, 1996, p. 28).

Parece-me evidente que os objetos naturais se distinguem dos fabricados com madeiras, palhas ou barros. Estes são "suportes para o vodu", na expressão de Gell (1992), índices do símbolo ou do fetiche ou da santidade do Santo. A linguagem iconográfica do índice de um protótipo na imagem da igreja que é reproduzida para os oratórios familiares, a participação nas festas do padroeiro traz santidade, bênçãos e saúde para o povo. No caso, a própria dança do curussé e as festas de Santo como rituais são obras de arte usadas para trazer bênçãos, realizar curas e unir os opostos. A pluralidade de agentes (Santos, pedras, madeiras, pessoas e outros) implica em pluralidade de agências que os objetos-sujeitos têm sobre a fabricação e transformação dos corpos e do pueblo. Os vodus, Santos ou "os deuses são antes de tudo uma forma e matéria, conjunto de substâncias tomadas da natureza, são imagens, uma importante alusão ao corpo humano ou a metonímica do corpo humano" (AUGÉ, 1996, p. 53). 
Observo que os materiais utilizados para as obras de arte iconográficas são de fundamental importância porque já trazem em si as diferenças que serão aplicadas no corpo humano ou no artefato, o tipo de madeira, as vestes, o que os Santos carregam nas mãos, a auréola na cabeça e outros sinais que vão marcando a identidade do Santo, pois não são todos iguais! Assim também os Chiquitanos se identificam nas suas diferenças como podem, mas não querem ser indígenas no geral, sem cultura nem valores que consideram importantes, tais como a herança que receberam na Missão de Chiquitos.

Por outro lado, as esculturas e pinturas possuem um sistema de comunicação com o "Deus supremo" porque são almas espirituais e, assim, elas preparam as pessoas para estas relações com os diferentes mundos dos espíritos, dos animais e dos afins, dos vegetais e minerais (mesmo que aparentemente inanimados). De alguma forma, também as montanhas, as terras e os rios são predados ritualmente para a sobrevivência humana. Os hitchis oferecem aos seres humanos os elementos da natureza dos quais são "donos". Os Santos, que possuem relação íntima com o Deus criador da natureza, auxiliam nesta tarefa de santificação, ou seja, dizem que São João Batista é dono do fogo; Santa Bárbara, dos raios; Nossa Senhora da Conceição, das águas etc. e todos estes elementos fazem parte de suas relações e de seus corpos. Os Santos são seres espirituais que parecem fazer também a mediação com esse mundo dos hitchis, apesar de aparecerem às vezes como mundos opostos e, por vezes, são demonizados por algumas correntes do pensamento cristão. Os Santos possuem propriedades e atributos que os identificam e thes permitem cuidar de algumas esferas da vida humana e dos elementos da natureza, como os hitchis, neste caso, São João Batista domina o fogo e a água sem conflitos, como acontece no ritual do dia 23 de junho, quando vão banhar-se e ao Santo para depois passar pelo meio do fogo. Estes seres espirituais não são incongruentes, mas por vezes aparecem na fala dos Chiquitanos de forma distinta, pois com os hitchis das Serras, das águas profundas, lugares mais desconhecidos, penso que existe mais temor ainda e o esforço é para pacificá-los, como fizeram com os Santos. Isso não quer dizer que o catolicismo oficial não foi elaborando formas de desclassificar e 
substituir as cosmologias tradicionais chiquitanas e, na linguagem atual, muitas vezes os hitchis acabam sendo associados automaticamente a representações do mal, às vezes assumidos por alguns Chiquitanos mesmos. Alguns jesuítas eram mais compreensivos que outros para os rituais tradicionais indígenas e o mesmo acontece atualmente nas relações sociais.

Penso que estes e outros adornos dos Santos e dos Chiquitanos identificam e influenciam diretamente as pessoas com quem se relacionam no sentido de que identificam as funções litúrgicas, seu lugar na sociedade, se é parente ou inimigo. Por exemplo, as flechas identificam São Sebastião, que é invocado contra as pestes, San Josecito del Sari possui um esquadro na mão direita e o menino Jesus no braço esquerdo, o que lhe dá condições de organizar o sustento da família e assim por diante, cada Santo terá a sua especificidade. No caso dos auxiliares da Missa (monaguillos), estes fazem questão de se vestirem com túnicas brancas para estarem em torno do altar. Assim predam centripetamente, na linguagem de Carlos Fausto (2001), transformam o inimigo através de alianças entre opostos. Não vamos encontrar um Chiquitano desafiando diretamente ou falando alto pois não é de sua índole confrontar, mas trazer seus conteúdos para dentro e torná-lo familiar. Penso que esta é a perspectiva chiquitana e o objetivo de muitos casamentos dos Chiquitanos com os de fora.

No final desta reflexão, quero ressaltar mais uma vez que se tratam de relações sociais em movimento na conformação desta etnia chiquitana na fronteira: primeiro entre as pessoas concretas na família e depois na comunidade, isso com a mediação do aspecto religioso da relação com os Santos que são patronos de pessoas, de famílias e de comunidades (pueblos). Este esforço gigantesco dos Chiquitanos de harmonizar os opostos sociais encontra respaldo na sua história, pois tiveram que conviver no processo colonizador com outras etnias, com os missionários jesuítas, com os crucenhos e com os fazendeiros até os dias de hoje. Isso se reflete nas suas formas de sensibilidade estética nas danças de roda, nas formas de celebração dos seus padroeiros, na forma de trançar a palha de buriti para fazer os seus artefatos ou ao amassar o barro para fazer os potes, todas formas que opõem e, ao 
mesmo tempo, aproximam opostos, como diria meu orientador, Sergio Baptista da Silva, apontado na epígrafe deste escrito.

Penso que trabalhar as relações com os Santos pelo viés da estética, assumindo-os como obras de arte, trouxe uma relativização que é própria da antropologia e assim não caímos tão fácil na tentação de substancializar este campo de estudo, nem os Chiquitanos e muito menos os Santos. Muito ainda pode-se dizer a respeito dessa noção, abrindo várias janelas, principalmente após a presença dos restauradores das igrejas liderados pelo jesuíta Hans Roth na Chiquitania. Aqui somente iniciamos um diálogo.

\section{Referências bibliográficas}

AUGÉ, Marc. Dios como objeto: símbolos-cuerpos-materias-palabras. Barcelona: Gedisa, 1996.

BACHELARD, Gaston. A casa, o porão e sótão. In: A poética do espaço. São Paulo: Martins Fontes, 2008. p. 199-218.

DESCOLA, Philippe. Más allá de la naturaleza y la cultura. Etnografías Contemporáneas, Buenos Aires, v. 1, n. 1, p. 93-114, abr. 2005.

FAUSTO, Carlos. Inimigos Fiéis: história, guerra e xamanismo na Amazônia. São Paulo: EDUSP, 2001.

GALLOIS, Dominique T. Arte iconográfica Waiãpi. In: VIDAL, Lux (Org.). Grafismo indígena. São Paulo: Studio Nobel/Edusp/Fapesp, 1992. p. 209-230.

GEERTZ, Clifford. A interpretação das culturas. Rio de Janeiro: LTC, 1978.

GELL, Alfred. The technology of enchantment and the enchantment of technology. In: COOTE, Jeremy; SHELTON, Anthony (Org.). Anthropology: art and aesthetics. Oxford: Clarendon Press, 1992. p. 40-63.

JUSTINIANO, Oscar Tonelli. Reseña histórica, social y económica de la Chiquitania. Santa Cruz de la Sierra: Editorial El País, 2004.

LIMA, Edilene Coffaci de; SMILJANI, Maria Inês; FERNANDES, Ricardo Cid. Uma Antropologia Engajada: entrevista com Terence Turner. Campos, Curitiba, v. 9, n. 2, p. 139-157, 2008. 
MAUSS, Marcel. Oeuvres. Paris: Édition de Minuit, 1974.

MILLER, Joana. As coisas: os enfeites corporais e a noção de pessoa entre os Mamaindê (Nambiquara). 2007. 332 f. Tese (Doutorado em Antropologia) - Museu Nacional, [2007].

OBEYESEKERE, Gananath. The apotheosis of Captain Cook: European mythmaking in the Pacific. Chicago: Chicago University Press, 1997.

SAHLINS, Marshall. How 'Natives' Think: About Captain Cook, For Example. Chicago: University of Chicago Press, 1995.

SANS, Manuel Serrano y. Relación de las costumbres y relación de los índios Manasicas, por el Hermano Lucas Caballero, de la Compañía de Jesús: estudio preliminar y edición del ms de 1706. Madrid: Imprenta Góngora, 1933.

SEEGER, Anthony et al. A construção da pessoa nas sociedades indígenas brasileiras. In: OLIVEIRA FILHO, João Pacheco (Org.). Sociedades Indígenas e Indigenismo no Brasil. Rio de Janeiro: Marco Zero/UFRJ, 1987. p. 11-29.

SILVA, Sérgio Baptista da. Dualismos e cosmologia Kaingang: o xamã e o domínio da floresta. Horizontes Antropológicos, Porto Alegre, v. 8, n. 18, p. 189-209, dez. 2002.

TEIXEIRA-PINTO, Márnio. Ieipari: Sacrifício e Vida Social entre os Índios Arara (Caribe). São Paulo/Curitiba: Hucitec/Anpocs/Editora UFPR, 1996.

TURNER, Terence. The Ge and Bororo Societies as Dialectical Systems: a general model. In: MAYBURY-LEWIS, D. (Org.). Dialectical Societies. Harvard: Harvard University Press, 1979. p. 147-178.

VIDAL, Lux B. Iconografia e grafismos indígenas, uma introdução. In: VIDAL, Lux (Org.). Grafismo indígena. São Paulo: Studio Nobel/Edusp/Fapesp, 1992. p. 13-17.

VIDAL, Lux B.; LOPES DA SILVA, Aracy. Antropologia estética: enfoques teóricos e contribuições metodológicas. In: VIDAL, Lux (Org.). Grafismo indígena. São Paulo: Studio Nobel/Edusp/Fapesp, 1992. p. 369-402.

VIDAL, Lux; MÜLLER, Regina P. Pinturas e adornos corporais. In: RIBEIRO, Darcy; RIBEIRO, Berta (Orgs.). Suma etnológica brasileira. Arte Índia. Petrópolis: Vozes/FINEP, 1987. p. 119-148. v. 3.

VIVEIROS DE CASTRO, Eduardo. Os pronomes cosmológicos e o perspectivismo ameríndio. Mana, Rio de Janeiro, v. 2, n. 2, p. 115-144, out. 1996.

Araweté: o povo do Ipixuna. Lisboa: Editora Assírio \& Alvim, 2000.

Espaço Ameríndio, Porto Alegre, v. 6, n. 2, p. 137-177, jul./dez. 2012. 
ALOIR PACINI - Um perspectivismo ameríndio e a cosmologia anímica chiquitana

A Inconstância da Alma Selvagem e Outros Ensaios de Antropologia. São Paulo: Cosac \& Naify, 2002.

Espaço Ameríndio, Porto Alegre, v. 6, n. 2, p. 137-177, jul./dez. 2012. 